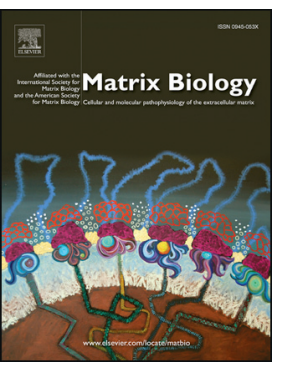

\title{
Connective tissue growth factor (CTGF) from basics to clinics
}

\section{Yasaman Ramazani $^{a}$, Noël Knops ${ }^{a, b}$, Mohamed A. Elmonem ${ }^{a, c}$, Tri Q. Nguyen ${ }^{d}$, Fanny Oliveira Arcolino ${ }^{a}$, Lambert van den Heuvel ${ }^{\mathrm{a}, \mathrm{e}}$, Elena Levtchenko ${ }^{\mathrm{a}, \mathrm{b}}$, Dirk Kuypers ${ }^{f}$ and Roel Goldschmeding ${ }^{d}$}

\author{
a - Department of Development and Regeneration, University of Leuven, Leuven, Belgium \\ b - Department of Pediatric Nephrology and Solid Organ Transplantation, University Hospitals Leuven, Leuven, Belgium \\ c - Department of Clinical and Chemical Pathology, Faculty of Medicine, Cairo University, Cairo, Egypt \\ $\boldsymbol{d}$ - Department of Pathology, University Medical Center Utrecht, Utrecht, The Netherlands \\ e - Department of Pediatrics, University Medical Center Radboud, Radboud, The Netherlands \\ $\boldsymbol{f}$ - Department of Nephrology and Renal Transplantation, University Hospitals Leuven, Leuven, Belgium
}

Correspondence to Roel Goldschmeding: R.Goldschmeding@umcutrecht.nl

https://doi.org/10.1016/j.matbio.2018.03.007

\begin{abstract}
Connective tissue growth factor, also known as CCN2, is a cysteine-rich matricellular protein involved in the control of biological processes, such as cell proliferation, differentiation, adhesion and angiogenesis, as well as multiple pathologies, such as tumor development and tissue fibrosis. Here, we describe the molecular and biological characteristics of CTGF, its regulation and various functions in the spectrum of development and regeneration to fibrosis. We further outline the preclinical and clinical studies concerning compounds targeting CTGF in various pathologies with the focus on heart, lung, liver, kidney and solid organ transplantation. Finally, we address the advances and pitfalls of translational fibrosis research and provide suggestions to move towards a better management of fibrosis.
\end{abstract}

(C) 2017 Elsevier B.V. All rights reserved.

\section{CTGF structure and regulation}

\section{Structure of the CTGF gene and protein}

CTGF (connective tissue growth factor), also known as CCN2, is one of the best-studied members of the CCN family [1], a family of regulatory proteins of the extracellular matrix (ECM) sharing a structurally related composition of functional domains. The acronym CCN was conceptualized after the initials of the first three proteins discovered in this family, namely: Cysteine rich angiogenic inducer 61 (CYR61), CTGF and Nephroblastoma overexpressed protein (NOV) [2]. Other members of the family include the WNT1 inducible signaling pathway proteins (WISP1, WISP2 and WISP3) also known as CCN4, CCN5 and CCN6, respectively [1]. The CCNs are involved in the control of a variety of important biological functions, including cell proliferation, differentiation, adhesion and angiogenesis, as well as multiple pathological processes, such as tumor development and tissue fibrosis [3]. Apart from CCN5, all CCN family members are composed of four functionally distinct conserved regions: an insulin-like growth factor (IGF)-binding protein domain next to a von Willebrand factor type C repeat (together forming the $\mathrm{N}$-terminal fragment), and a thrombospondin type 1 repeat next to a cysteine knot (together forming the C-terminal fragment). The nonconserved hinge between domains 2 and 3 is subject to proteolytic cleavage [4] (Fig. 1).

The CTGF gene (6q23.2) is a relatively short gene composed of 5 exons that code for a 349-amino acid protein. A novel splice variant of CTGF encoding the $\mathrm{C}$-terminal domain has been identified in the pediatric precursor $\mathrm{B}$ cell acute lymphoblastic leukemia which may be involved with tumorigenesis [5]. 


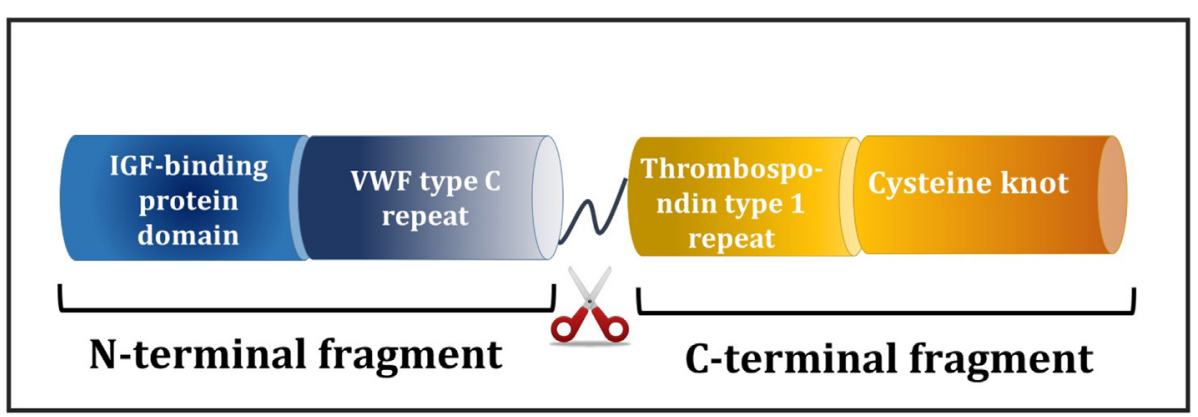

Fig. 1. With the exception of CCN5, all CCN family members are composed of four conserved regions: an insulin-like growth factor (IGF)-binding protein domain, a von Willebrand factor type C repeat, a thrombospondin type 1 repeat, and a cysteine knot. While each domain can have its own biological function(s), the different domains together may provide scaffolds for specific orchestration of crosstalk between multiple signaling pathways. The hinge between domains 2 and 3 can be cleaved by the activity of number of different proteases.

The CTGF gene and protein are highly conserved among vertebrate species. When comparing to human CTGF, the mouse ortholog exhibits $91 \%$ base pair identity and $95 \%$ amino acid similarity, while the zebrafish ortholog shows $78 \%$ identity and $87 \%$ similarity compared to humans. CTGF expression was initially discovered in endothelial cells and fibroblasts associated with connective tissue regeneration and wound healing [6,7]. CTGF RNA has been detected in many tissues, including smooth muscles, thyroid, spleen, kidney, prostate and endometrium, while high levels of CTGF protein have been reported in the cerebral cortex, smooth muscles, lymph nodes, lung, liver, gastrointestinal tract, endometrium and skin [8].

\section{Regulation of CTGF}

Contrary to the embryonic stage, where CTGF is highly expressed mediating renal, cardiovascular and skeletal development, the expression of CTGF is rather limited during adulthood. It is regulated at the transcriptional, post-transcriptional and (post-)translational levels by a variety of factors. At the transcriptional level, CTGF expression is induced by stimuli such as growth factors, cytokines, hormones, mitogens, ultraviolet light, oxygen deprivation and mechanical stress [9]. These external stimuli induce directly - or through crosstalks with cell surface receptors - the recruitment of transcription factors that drive the expression of CTGF. Most often, de novo synthesis of transcription factors is not necessary [4]. Transforming growth factor $\beta$ (TGF $\beta$ ) is a master regulator of tissue growth, regeneration, remodeling and fibrosis and most TGF $\beta$ responses involve CTGF stimulation at some level, such as the stimulation of ECM components, the proliferation of fibroblasts, osteoblasts and astrocytes, wound healing, and fibrosis [10-12]. The signaling molecules involved in crosstalk and integration of TGF $\beta$ and CTGF effects are numerous and variable, depending on the cell type and the physiological or pathological process involved. For instance, while
TGF $\beta$ stimulated Smads are necessary for induction of CTGF in normal fibroblasts and basal CTGF induction in scleroderma fibroblasts, maintenance of CTGF expression is independent of Smads [13].

Key transcription coactivators and transcriptional factors inducing CTGF expression are YAP (yesassociated protein)/TAZ (transcriptional coactivator with PDZ-binding motif)/TEAD (transcriptional enhancer factor TEF-1) and Ets1 (ETS proto-oncogene 1). YAP/TAZ induce the expression of CTGF in corneal epithelial, kidney epithelial and endothelial cells among others [14-16]. Very recently, it was demonstrated that YAP causes activation of hepatic stellate cells in mice and that TAZ, in a TGF $\beta$-dependent mechanism, upregulates CTGF in kidney epithelial cells $[17,18]$. Ets 1 is another potent stimulator of CTGF in modulating ECM remodeling in fibroblasts, endothelial cells and cancer cells [19-22] (Fig. 2).

Table 1 provides the overview of the chemical compounds with therapeutic potential that are experimentally capable of reducing CTGF expression as well as different members of the micro RNA (mi-RNA) family that are discovered to be important in regulation of CTGF.

As a secreted soluble protein of 36-38 kD, CTGF can also be found in the extracellular body fluids including blood plasma, from where it is eliminated by glomerular filtration in the kidney, and in the liver by uptake in hepatocytes. Full length CTGF is eliminated through a rapid route, which is mediated by low-density lipoprotein receptor-related protein 1 (LRP1) binding on the hepatocytes and, to a lesser extent, $(12 \%$ of total CTGF) by the kidney [53]. The C-terminal fragments of CTGF, similar to the full length CTGF, is cleared LRP1 binding on hepatocytes, which is a faster route than glomerular filtration [53]. Full length CTGF and its $\mathrm{N}$-terminal and $\mathrm{C}$-terminal fragments are filtered by the glomeruli and then reabsorbed completely from primary urine by the megalin-cubulin complex on proximal tubular epithelial cells. If reabsorption fails due to tubular dysfunction, especially the N-terminal CTGF fragment tends to accumulate in the voided 


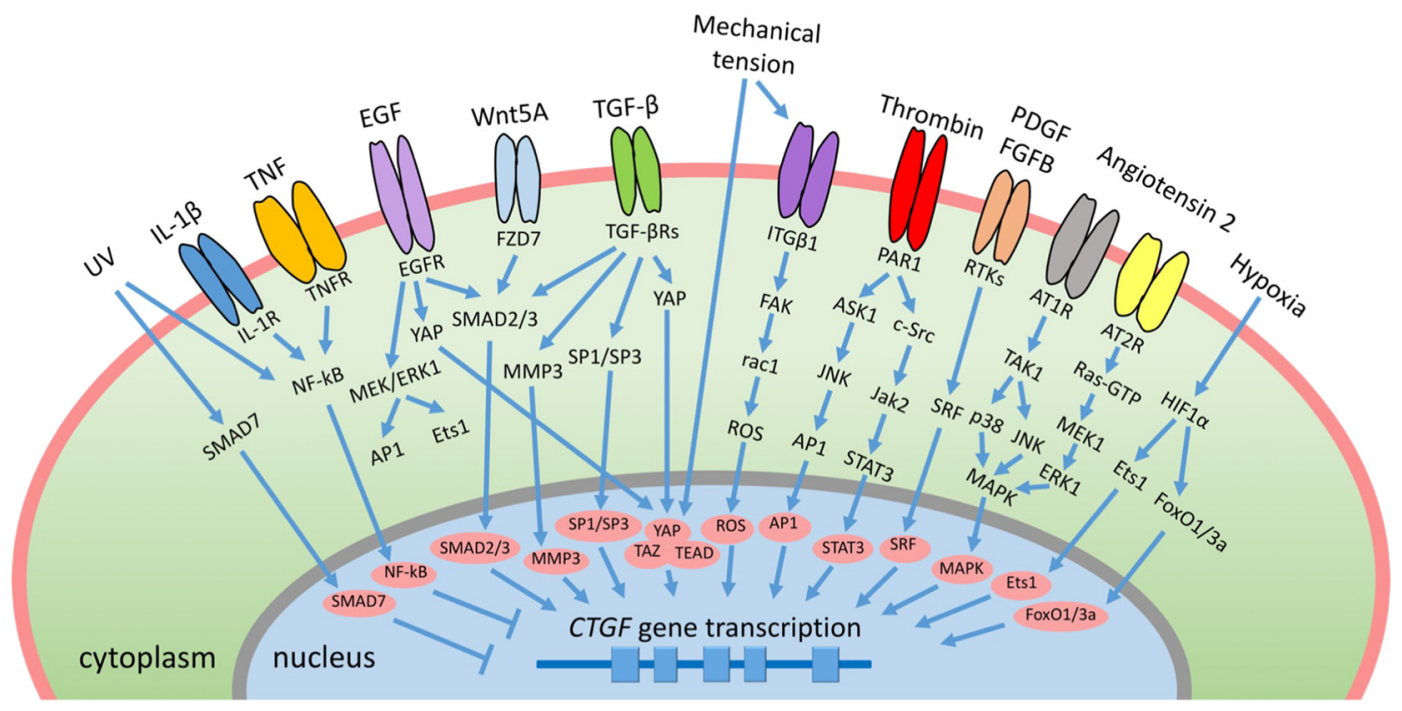

Fig. 2. External stimuli directly or through crosstalks, initiate signaling pathways that recruit transcription factors to the nucleus. These factors, based on the context in different cell types, inhibit or stimulate the expression of CTGF. CTGF expression is mainly regulated at the transcription level by the key transcription factors YAP/TAZ and Ets1 among others [9,23-35]. AP1: activator protein 1; ASK1: apoptosis signal-regulating kinase 1; AT1R: angiotensin 2 type 1 receptor, AT2R: angiotensin 2 type 2 receptor; c-Src: proto-oncogene c; EGF: epidermal growth factor; EGFR: epidermal growth factor receptor; Ets1: ETS proto-oncogene 1; FAK: focal adhesion kinase; FGFB: fibroblast growth factor 2; FOXO1/3a: forkhead box protein O1/forkhead box protein O3a; FZD7: frizzled 7; HIF1 $\alpha$ : hypoxia- inducible factor 1a; IL-1R: interleukin 1 receptor; IL1 $\beta$ : interleukin $1 \beta$; ITG $\beta 1$ : integrin $\alpha 3 / \beta 1$; JAK2: Janus kinase 2; JNK: c-Jun N-terminal kinase; MAPK: mitogen-activated protein kinase; MEK/ERK: mitogen-activated protein kinase kinase/extracellular signal-regulated kinase; MMP3: matrix metalloprotease 3; NFk-B: nuclear factor kappa-lightchain-enhancer of activated B cell; PAR1: protease- activated receptor 1; PDGF: platelet-derived growth factor; Rac1: Rasrelated C3 botulinum toxin substrate; RAS-GTP: RAS-guanosine triphosphate; ROS: reactive oxygen species; RTK: receptor tyrosine kinase; SP1/SP3: specificity protein 1/specificity protein 3; SRF: serum response factor; STAT3: signal transducer and activator of transcription 3; TAK1: transforming growth factor beta-activated kinase 1; TAZ: transcriptional coactivator with PDZbinding motif; TEAD: transcriptional enhancer factor TEF-1; TGF $\beta$ : transforming growth factor $\beta$; TGF $\beta$ : transforming growth factor $\beta$ receptor; TNF: tumor necrosis factor; TNFR: tumor necrosis factor receptor; UV: ultra violet; YAP: yes-associated protein.

urine [54,55]. The N-CTGF fragments do not bind to LRP1, thereby escaping hepatic elimination, and are less rapidly cleared than the full length and C-terminal

Table 1. Overview of chemical compounds and mi-RNAs reducing CTGF expression.

\begin{tabular}{|c|c|}
\hline Regulatory factor & Reference \\
\hline Sinomenine & [36] \\
\hline Curcumin & [37] \\
\hline Caffeine & [38] \\
\hline Statins & [39] \\
\hline DN-9693 (a cAMP: phosphodiesterase inhibitor) & [40] \\
\hline$m i-R N A-15 a / b$ & [41] \\
\hline mi-RNA-18a & [42] \\
\hline$m i-R N A-18 b$ & [43] \\
\hline$m i-R N A-19 b$ & [44] \\
\hline$m i-R N A-26 a$ & {$[44,45]$} \\
\hline$m i-R N A-26 b$ & [44] \\
\hline mi-RNA-29 & [43] \\
\hline$m i-R N A-30$ & [46] \\
\hline$m i-R N A-133$ & [46] \\
\hline$m i-R N A-145$ & {$[47,48]$} \\
\hline mi-RNA-205 & [49] \\
\hline$m i-R N A-214$ & {$[50,51]$} \\
\hline$m i-R N A-375$ & [52] \\
\hline
\end{tabular}

fragment. As a consequence, N-CTGF is more easily detected in blood plasma, and tends to accumulate when renal function is compromised.

\section{Biological functions and mechanisms of action}

The biological roles of CTGF are considered to be regulatory: I) It is capable to bind to specific receptors to initiate signal transduction, II) It can bind cytokines, mediating their binding to the cell-surface receptors and initiation of downstream signaling pathways, III) CTGF mediates the matrix turnover by binding to ECM proteins and IV) It is involved in the regulation of the activity of cytokines and growth factors through modulation of crosstalk between signaling pathways.

\section{CTGF binding to cell surface receptors}

CTGF binds several receptors, such as integrins (ITGs), heparan sulfate protoglycans (HSPGs), lipoprotein receptor related proteins (LRPs) and tyrosine kinase (TK) receptors [4]. CTGF exerts many of its functions through binding to integrin receptors. In 
some cases, LRPs and HPSGs act as co-receptors [56]. For instance, in liver fibrosis, in activated hepatic stellate cells, CTGF binds to integrin $\alpha_{5} \beta_{3}$ with HSPGs acting as co-receptors [57]. Moreover, CTGF binds to $\alpha_{5} \beta_{1}$ and HPSG in pancreatic stellate cells to mediate their adhesion, proliferation, migration and collagen synthesis in pancreatic fibrosis [58].

CTGF, through direct binding to $\alpha_{1} \beta_{3}$ integrin, strengthens the adhesion of chondrosarcoma-derived chondrocytes to fibronectin [59].

CTGF binds to LRP1 on hepatocytes and LRP6 on kidney cells, which is discussed in depth later in this review. CTGF mediates fibrosis in cardiomyocytes partly through binding to TK receptor A [60]. Interaction of CTGF with syndecan 4, another receptor in mouse embryonic fibroblasts, is necessary for the motility of these cells [61]. CTGF binds to fibroblast growth factor receptor 2 and, in collaboration with fibroblast growth factor 2, regulates bone metabolism in osteoblasts [62]. Receptor activator of nuclear factor KB (RANK), osteoprotegrin and dendritic transmembrane protein are other receptors to which CTGF binds, and through which it enhances osteoclast differentiation [63,64]. In human corneal fibroblasts, binding of CTGF to yet another receptor, mannose 6 phosphate/insulin like growth factor 2 receptor is necessary for fibroblast proliferation [65].

\section{CTGF binding to cytokines}

CTGF can directly bind to cytokines regulating their availability and activity. For instance, CTGF binds vascular endothelial growth factors (VEGFs), fibroblast growth factor 2 (FGF-2), bone morphogenic protein 4 (BMP4), TGF $\beta$ and platelet-derived growth factor $B$ (PDGFB) [66-69]. The downstream effects of binding of CTGF to the cytokines and growth factors are context-dependent. For instance, while CTGF inhibits the VEGF-A signaling pathway in angiogenesis (induced by hypoxia or ischemia), in kidney fibrosis, it induces the VEGF-C induced lymphangiogenesis $[66,69]$.

\section{CTGF binding to ECM proteins}

CTGF binds to components of the ECM such as fibronectin, aggrecan and HSPGs [70]. The binding of CTGF to ECM components is central to the functions of CTGF in cell adhesion and motility (discussed further in detail) as well as its role as the mediator of ECM turnover during tissue remodeling in (patho) physiological conditions [71].

\section{CTGF modulating crosstalk between signaling pathways}

There is not much known about the role of CTGF as the mediator in linking signaling pathways. However, based on multiple evidence on the binning of CTGF to soluble growth factors on the one hand and its binding to multi-ligand receptors on the other hand, CTGF fulfills the common features of a matricellular protein very well. CTGF can facilitate specific downstream effects via binding to contextdependent receptors such as ITGs, HSPGs and LRPs (see above) [56].

\section{CTGF functions in development}

CTGF appears to play an important role in a myriad of biological processes active in different stages during development. CTGF knockout mice demonstrate developmental skeletal malformations, including impaired palatogenesis and rib-cage deformity. These mice die shortly after birth due to respiratory failure [72]. Although the responsible mechanisms are not well elucidated, CTGF seems to be important for cellular proliferation, adhesion and cell spreading during of palatogenesis [73]. During development, CTGF is highly expressed in vasculature, heart, lung and bone tissue [74]. Interestingly, CTGF was found to be involved in regulation of energy metabolism in bone tissue, and CTGF deficiency in murine chondrocytes caused reduced expression of several glycolytic enzymes. CTGF deficiency also imbalanced protein synthesis, with excessive consumption of essential amino acids and thereby critically reducing the availability of essential amino acids [75]. CTGF also induces differentiation of murine neural progenitors to astrocytes through p44/42 mitogen MAPK signaling and fibronectin deposition [10]. In addition, CTGF drives the early differentiation of myoblasts in mice, while it inhibits the terminal differentiation of myoblasts [76].

\section{CTGF as mediator of cellular events}

\section{Cell adhesion and motility}

Inhibiting CTGF in vitro using anti-CTGF neutralizing antibody inhibits the attachment of cells on the surface, indicating the necessity of CTGF for adhesion of the cells to the ECM; however, as previously stated, CTGF is neither a cell-membrane molecule nor a structural component of the ECM, but rather bridges the latter (including fibronectin, perlecan, vitronectin, and decorin) to integral cell surface molecules like ITGs and connexin $43[4,77]$. In fibroblasts, CTGF binds to ITGs and HSPGs and initiates phosphorylation of focal adhesion kinase (FAK) and extracellular signal regulated kinase (ERK), activates F-actin, paxillin and RhoA and enhances the formation of focal adhesions [77].

CTGF overexpression in some cancers enhances the motility of cancer cells and metastasis. For instance, CTGF induces the motility of breast cancer cells through integrin $\alpha_{5} \beta_{3}$ and phosphorylation of ERK $1 / 2$ and through P38 phosphorylation in non-small cell 
lung cancer $[77,78]$. Although CTGF has been associated with metastasis of several cancers, it actually enhances anoikis and reduces metastasis in lung cancer. This implies the context-dependent role of CTGF in regulating cell motility [79].

\section{Cell survival, cell cycle arrest and senescence}

It has been demonstrated that CTGF, by activating mitogen activated protein kinase (MAPK) phosphatase 1 (MPK1, or Dual Specificity Phosphatase 1) and stabilization of anti-apoptotic protein B-cell lymphoma 2 (BCL-2), enhances cell survival in kidney mesangial cells [80]. This is contrary to the prior observation that CTGF causes cell cycle arrests in kidney mesangial cells [81]. In cellular senescence, typically identified as prolonged cell cycle arrest, CTGF is produced in large amounts, and might stimulate senescence-associated inflammation and fibrosis [82].

\section{CTGF in connective tissue remodeling}

The process of wound healing occurs through the recruitment of immune cells to the site of injury and activation of injured epithelial/endothelial cells. These cells produce profibrotic and pro-inflammatory cytokines, which induce trans-differentiation of epithelial cells, local or recruited mesenchymal cells (fibroblasts and pericytes) and endothelial cells, to become myofibroblasts, and increase the production of ECM. This process will cease by elimination of the initial insults by the immune system. However, if the injury persists, repeats, or gets too intense, or if the process of repair becomes dysregulated, the normal tissue repair will proceed to excessive, and at some point, irreversible fibrosis [83,84].

Wound healing and tumor-induced connective tissue responses are indistinguishably similar comprising inflammation, cell proliferation and tissue remodeling. Cells involved in wound healing and tumor stroma induction produce several cytokines and chemokines to enhance cell proliferation, ECM production, and formation of new blood vessels [85]. CTGF is one of the main regulators of the molecular events that occur in the spectrum of wound healing to fibrosis through its interactions with several receptors, growth factors and signaling molecules (Fig. 3).

Upon injury in the kidney, damaged tubular epithelial cells get activated and produce proinflammatory and profibrotic factors such as CTGF and TGF $\beta$. These cytokines further induce the dedifferentiation of proximal tubule epithelial cells to acquire a phenotype resembling contractile myofibroblasts which are the main mediators of matrix turnover [84]. In several in vitro and in vivo kidney fibrosis models during the maladaptive response of the proximal tubule cells to injury, these cells get arrested in the G2/M phase of the cell cycle with activation of the DNA damage repair (DDR) mechanisms that result in the production of profibrotic factors $[86,87]$. This pathway has now been demonstrated to essentially involve several components of the DDR $[33,88,89]$. It will be interesting to further elucidate how production of CTGF by cell cycle-arrested tubular epithelial cells may relate to their trans-differentiation to myofibroblasts and other aspects of kidney fibrosis. For this,

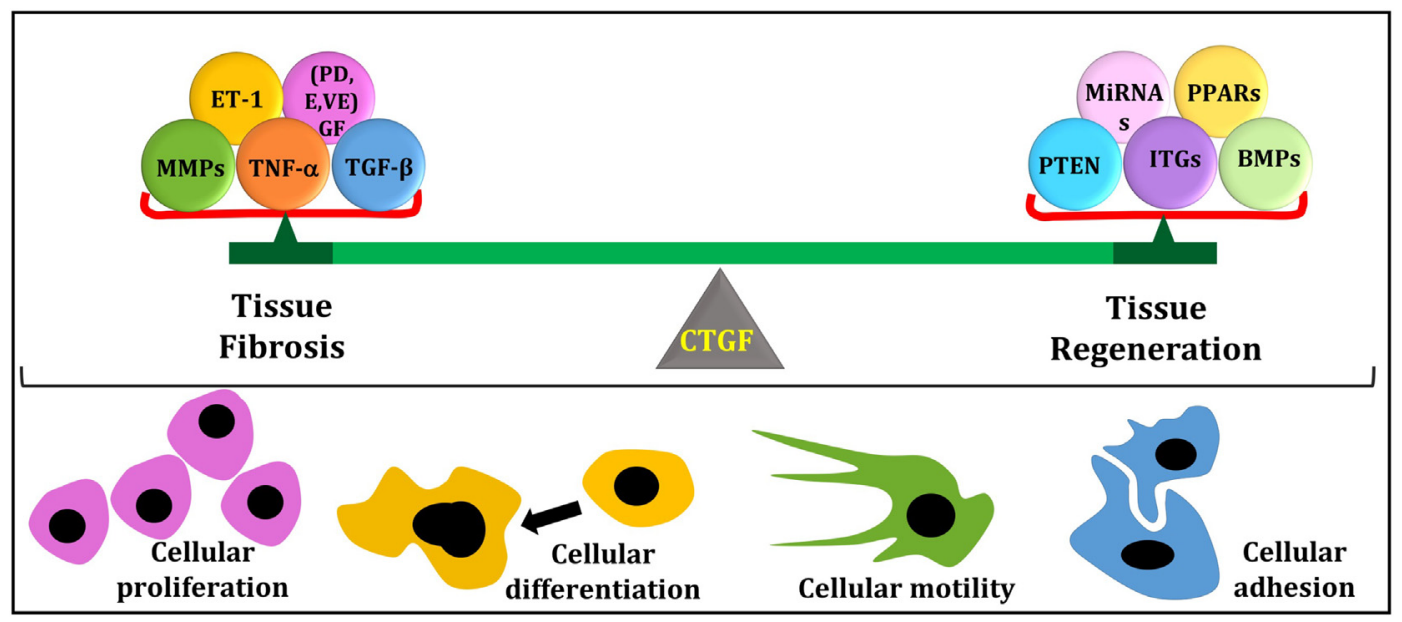

Fig. 3. CTGF mediates both tissue regeneration and fibrosis through its interaction with several factors which results in cell proliferation, differentiation, motility, adhesion and matrix turnover. The pathways involved in fibrosis are complex and tissue-specific. However, the following factors are commonly involved in manifestation of fibrosis in different tissues: ET-1: endothelin-1; (PD, E, VE) GF: platelet-derived, epidermal and vascular endothelial growth factor; MMPs: matrix metalloproteases; TNF- $\alpha$ : tumor necrosis factor $\alpha$; mi-RNA: micro RNA, PPAR: peroxisome proliferator-activated receptor; PTEN: phosphatase and tension homolog; ITGs: integrins; BMPs: bone morphogenic proteins. 
Table 2. List of molecular interventions targeting CTGF in different pathological contexts.

\begin{tabular}{|c|c|c|c|c|}
\hline Disease setting & $\begin{array}{l}\text { Source/level of } \\
\text { intervention }\end{array}$ & Intervention & Results & Reference \\
\hline \multicolumn{5}{|c|}{ Carcinogenesis and tumor development } \\
\hline Metastatic melanoma & $\begin{array}{l}\text { Human/melanoma cell } \\
\text { lines }\end{array}$ & $\begin{array}{l}\text { Anti-CTGF antibody (FG-3019/ } \\
\text { pamrevlumab) }\end{array}$ & Inhibition of progression & {$[99]$} \\
\hline Pancreatic tumor & Mouse/systemic & $\begin{array}{l}\text { Anti-CTGF antibody (FG-3019/ } \\
\text { pamrevlumab) }\end{array}$ & Reduction of tumor size & {$[219]$} \\
\hline $\begin{array}{l}\text { High grade serous ovarian } \\
\text { cancer }\end{array}$ & $\begin{array}{l}\text { Human/HGSOC tumor } \\
\text { tissue }\end{array}$ & $\begin{array}{l}\text { Anti-CTGF antibody (FG-3019/ } \\
\text { pamrevlumab) }\end{array}$ & $\begin{array}{l}\text { Inhibition of migration and } \\
\text { peritoneal cell adhesion }\end{array}$ & {$[220]$} \\
\hline Ductal pancreas cancer & Mouse/systemic & $\begin{array}{l}\text { Anti-CTGF antibody (FG-3019/ } \\
\text { pamrevlumab; together with } \\
\text { gemcitabine) }\end{array}$ & Reduction of tumor size & [221] \\
\hline Glaucoma & Human/cribrosa cells & $\begin{array}{l}\text { Anti-CTGF antibody (FG-3019/ } \\
\text { pamrevlumab) }\end{array}$ & $\begin{array}{l}\text { Reduction of (fibronectin, fibrillin- } \\
1, \text { collagen } 1 \text {, and } \alpha \text {-smooth } \\
\text { muscle actin) }\end{array}$ & {$[102]$} \\
\hline \multicolumn{5}{|l|}{ Muscular diseases } \\
\hline $\begin{array}{l}\text { Duchenne muscular } \\
\text { dystrophy }\end{array}$ & Mouse/systemic & $\begin{array}{l}\text { Anti-CTGF antibody (FG-3019/ } \\
\text { pamrevlumab) }\end{array}$ & $\begin{array}{l}\text { Amelioration of impaired } \\
\text { muscle function and fibrosis }\end{array}$ & {$[111]$} \\
\hline \multicolumn{5}{|l|}{ Skin fibrosis (Scleroderma) } \\
\hline Skin fibrosis & Mouse/skin fibroblasts & $\begin{array}{l}\text { Anti-CTGF antibody (FG-3019/ } \\
\text { pamrevlumab) }\end{array}$ & $\begin{array}{l}\text { Attenuation of inflammation, } \\
\text { fibrosis and vascular damage }\end{array}$ & {$[117]$} \\
\hline \multicolumn{5}{|l|}{ Lung fibrosis } \\
\hline Lung fibrosis & Mouse/systemic & Anti-CTGF antibody & $\begin{array}{l}\text { Reduction of collagen type I } \\
\text { and alpha } 2 \text { promoter activity }\end{array}$ & {$[125]$} \\
\hline Lung fibrosis & $\begin{array}{l}\text { Rat/pulmonary } \\
\text { microvascular } \\
\text { endothelial cells }\end{array}$ & Anti-CTGF antibody & $\begin{array}{l}\text { Inhibition of fibroblast } \\
\text { transformation and decrease } \\
\text { in collagen }\end{array}$ & [222] \\
\hline Lung fibrosis & Mouse/systemic & $\begin{array}{l}\text { Anti-CTGF antibody (FG-3019/ } \\
\text { pamrevlumab) }\end{array}$ & $\begin{array}{l}\text { Attenuation of excessive } \\
\text { collagen disposition }\end{array}$ & {$[224]$} \\
\hline Lung fibrosis & $\begin{array}{l}\text { Human/embryonic } \\
\text { lung fibroblasts }\end{array}$ & Anti-CTGF antibody & $\begin{array}{l}\text { Decrease in endothelin- induced } \\
\text { a-smooth muscle actin } \\
\text { expression }\end{array}$ & {$[225]$} \\
\hline \multicolumn{5}{|l|}{ Cardiac fibrosis } \\
\hline $\begin{array}{l}\text { Myocardial fibrosis in } \\
\text { cardiomyopathy }\end{array}$ & Mouse (systemic) & $\begin{array}{l}\text { Anti-CTGF antibody (FG-3019/ } \\
\text { pamrevlumab) }\end{array}$ & $\begin{array}{l}\text { Improvement of left ventricular } \\
\text { function }\end{array}$ & {$[146]$} \\
\hline \multicolumn{5}{|l|}{ Liver fibrosis } \\
\hline Liver fibrosis & Mouse/systemic & Antisense CTGF oligonucleotide & $\begin{array}{l}\text { Reduction of collagen type I } \\
\text { induced by carbon tetrachloride }\end{array}$ & {$[226]$} \\
\hline Liver fibrosis & Rat/stellate cells & Antisense CTGF oligonucleotide & $\begin{array}{l}\text { Attenuation of stellate cells' } \\
\text { activity, reduction of TGF } \beta\end{array}$ & {$[174]$} \\
\hline Liver fibrosis & $\begin{array}{l}\text { Rat/primary stellate } \\
\text { cells }\end{array}$ & Antisense CTGF oligonucleotide & $\begin{array}{l}\text { Inhibition of stellate cells' } \\
\text { activation and reduction of ECM } \\
\text { genes }\end{array}$ & {$[175]$} \\
\hline $\begin{array}{l}\text { Hepatitis C-induced liver } \\
\text { fibrosis }\end{array}$ & $\begin{array}{l}\text { Human/hepatoma cell } \\
\text { lines }\end{array}$ & $\begin{array}{l}\text { Short hairpin-RNA mediated } \\
\text { knockdown of CTGF }\end{array}$ & $\begin{array}{l}\text { Reduction of } \alpha \text {-smooth muscle } \\
\text { actin and MMP2 expression }\end{array}$ & [227] \\
\hline Liver fibrosis & $\begin{array}{l}\text { Rat/immortalized } \\
\text { stellate cells }\end{array}$ & $\begin{array}{l}\text { Short hairpin-RNA mediated } \\
\text { knockdown of CTGF and } \\
\text { antisense CTGF oligonucleotide }\end{array}$ & $\begin{array}{l}\text { Reduction of proliferation and } \\
\text { activity of stellate cells and } \\
\text { reduction of collagen expression } \\
\text { and liver fibrosis }\end{array}$ & {$[176]$} \\
\hline \multicolumn{5}{|c|}{ Kidney fibrosis: tubulointerstitial diseases } \\
\hline $\begin{array}{l}\text { Interstitial fibrosis in } \\
\text { diabetic nephropathy }\end{array}$ & $\begin{array}{l}\text { Human/kidney } \\
\text { fibroblasts }\end{array}$ & Anti-CTGF antibody & $\begin{array}{l}\text { Partial inhibition of glucose- } \\
\text { induced matrix formation }\end{array}$ & [228] \\
\hline Renal interstitial fibrosis & Rat/interstitium & Antisense CTGF oligonucleotide & $\begin{array}{l}\text { Decrease of ECM proteins and } \\
\text { myofibroblast proliferation }\end{array}$ & {$[229,230]$} \\
\hline
\end{tabular}


Table 2 (continued)

\begin{tabular}{|c|c|c|c|c|}
\hline Disease setting & $\begin{array}{l}\text { Source/level of } \\
\text { intervention }\end{array}$ & Intervention & Results & Reference \\
\hline \multicolumn{5}{|l|}{$\begin{array}{l}\text { Kidney fibrosis: } \\
\text { tubulointerstitial diseases }\end{array}$} \\
\hline Renal interstitial fibrosis & $\begin{array}{l}\text { Human/tubule epithelial } \\
\text { cells }\end{array}$ & Antisense CTGF oligonucleotide & $\begin{array}{l}\text { Inhibition of TGF } \beta \text {-induced and } \\
\text { direct trans differentiation of } \\
\text { epithelial cells to myofibroblasts }\end{array}$ & [231] \\
\hline Renal interstitial fibrosis & Mouse/systemic & Antisense CTGF oligonucleotide & $\begin{array}{l}\text { Reduction of plasminogen } \\
\text { activator inhibitor } 1 \text { (PA- } 1 \text { ) and } \\
\text { tissue inhibitor of metalloprotease } \\
1 \text { (TIMP1) }\end{array}$ & {$[214]$} \\
\hline Renal interstitial fibrosis & $\begin{array}{l}\text { Human/tubule epithelial } \\
\text { cells }\end{array}$ & Antisense CTGF oligonucleotide & $\begin{array}{l}\text { Inhibition of TGF } \beta \text { induced } \\
\text { increase of plasminogen } \\
\text { activator inhibitor } 1\end{array}$ & [232] \\
\hline Renal interstitial fibrosis & $\begin{array}{l}\text { Human/tubule epithelial } \\
\text { cells }\end{array}$ & Antisense CTGF oligonucleotide & $\begin{array}{l}\text { Reduction of lymphangiogenesis } \\
\text { through decrease of VEGF-C }\end{array}$ & [188] \\
\hline \multicolumn{5}{|c|}{ Kidney fibrosis: glomerulonephropathies } \\
\hline Fibrosis & Rat/mesangial cells & Antisense CTGF oligonucleotide & $\begin{array}{l}\text { Inhibition of cell proliferation and } \\
\text { reduction of fibronectin }\end{array}$ & [233] \\
\hline $\begin{array}{l}\text { Crescentic } \\
\text { glomerulonephritis }\end{array}$ & $\begin{array}{l}\text { Rat/glomerular parietal } \\
\text { epithelial cells }\end{array}$ & Antisense CTGF oligonucleotide & $\begin{array}{l}\text { Inhibition of TGF } \beta \text { and PDGF- } \\
\text { induced ECM production }\end{array}$ & [234] \\
\hline Diabetic Nephropathy & Human/mesangial cells & $\begin{array}{l}\text { Antisense CTGF oligonucleotide } \\
\text { and anti-CTGF antibody }\end{array}$ & $\begin{array}{l}\text { Reduction of TGF } \beta \text { induced } \\
\text { increase of fibronectin (stimulated } \\
\text { by high glucose) }\end{array}$ & [235] \\
\hline Diabetic nephropathy & Rat/mesangial cells & Anti-CTGF antibody & $\begin{array}{l}\text { Inhibition of Fibronectin and } \\
\text { collagen IV production }\end{array}$ & [236] \\
\hline Diabetic nephropathy & Rat/interstitial fibroblasts & Antisense CTGF oligonucleotide & $\begin{array}{l}\text { Inhibition of advanced glycation } \\
\text { end products (AGE)-induced } \\
\text { collagen } 1 \text { production and leptin- } \\
\text { induced mitogenesis }\end{array}$ & {$[237,238]$} \\
\hline Diabetic nephropathy & Mouse/renal cortex & Antisense CTGF oligonucleotide & $\begin{array}{l}\text { Reduction of fibronectin, collagen } \\
\mathrm{I} \text { and } \mathrm{V} \text { and PAl-1 }\end{array}$ & [205] \\
\hline Diabetic nephropathy & Human/mesangial cells & $\begin{array}{l}\text { Antisense CTGF adenoviral } \\
\text { transduction }\end{array}$ & $\begin{array}{l}\text { Reduction of tissue inhibitor of } \\
\text { matrix metalloprotease and } \\
\text { fibronectin induced by advanced } \\
\text { glycated end-products }\end{array}$ & [239] \\
\hline Diabetic nephropathy & Mouse/podocytes & Anti-CTGF antibody & $\begin{array}{l}\text { Restoration of EMT induced by } \\
\text { high glucose }\end{array}$ & {$[240]$} \\
\hline Diabetic nephropathy & Mouse/glomeruli & $\begin{array}{l}\text { Anti-CTGF antibody (FG-3019/ } \\
\text { pamrevlumab) }\end{array}$ & $\begin{array}{l}\text { Amelioration of } \beta \text {-catenin } \\
\text { overexpression, reduction of } \\
\text { podocytes' EMT }\end{array}$ & [207] \\
\hline $\begin{array}{l}\text { Transplantation } \\
\text { Heart transplantation }\end{array}$ & Mouse/systemic & $\begin{array}{l}\text { Anti-CTGF antibody (FG-3019/ } \\
\text { pamrevlumab) }\end{array}$ & $\begin{array}{l}\text { Reduction of fibrotic lesions in } \\
\text { allografts and cardiomyocyte } \\
\text { hypertrophy }\end{array}$ & [241] \\
\hline
\end{tabular}

staining kidney biopsies for CTGF and other markers may yield important insights.

In the following section, we will elaborate on the roles of CTGF in multiple pathologies. Studies of the impact of molecular interventions to increase or impair CTGF availability and activity are listed in Table 2.

\section{Roles in specific pathological conditions}

\section{Carcinogenesis and tumor development}

The role of CTGF in carcinogenesis has been extensively studied with a focus on its interaction with TGF $\beta$, but it is becoming clear that the role of CTGF in cancer development is also determined by the synergistic effect of the network of CTGF with other CCN proteins and other molecules in tumor environment [79]. CTGF has been both positively and negatively correlated with evolution of tumors and metastases. For instance, while CTGF expression enhances the growth of hepatocellular carcinoma and early stages of colon carcinoma, it seems to have a protective effect against metastasis in later stages of colon cancer [90,91]. Of note, high CTGF expression is also associated with the aggressive inflammatory and stroma-rich phenotype of colorectal cancer [92]. CTGF expression is also increased in breast cancer (where it might regulate chemo-resistance) [93,94], chondrosarcomas, enchondroma, glioma, pancreatic cancer, thyroid carcinoma, chondrosarcoma, esophageal cancer, intrahepatic cholangiocarcinoma, neuroendocrine 
tumors, and squamous cell carcinoma of the tongue [95-97]. In a model of murine melanoma, the absence of CTGF impaired the ability of the malignant cells to dynamically remodel the ECM and metastasize. Moreover, in wild type mice injected with melanoma cell lines lacking CTGF, no metastasis was observed in the lungs [98]. CTGF is known to be vital for the progression of melanoma through the hypoxic induction of hypoxia-inducible factor 1 and $2 \alpha$ (HIF1 and HIF2 $\alpha$ ). In accordance, blocking CTGF with the antiCTGF monoclonal antibody, FG-3019/pamrevlumab, could inhibit the migration of human melanoma cell lines emphasizing the potential of CTGF as a therapeutic target in metastatic melanoma [99].

There are several mechanisms proposed for involvement of CTGF expression in different aspects of tumor biology, involving inflammation, cell proliferation, survival and motility but further discussion is beyond the scope of this review and is elaborated elsewhere [79]. To maintain the focus of this article on fibrosis, we have only mentioned few examples of such studies in Table 2. For a broader overview of drugs that modulate the tumor microenvironment, interested readers are encouraged to read a recent review in this field [85].

\section{Ocular and neural disorders}

CTGF is shown to be involved in the pathology of several ocular diseases where it has been implicated primarily in modulation of fibrosis and neovascularization through matrix metalloprotease 2 (MMP2) and VEGF. In proliferative diabetic retinopathy, an increasing amount of CTGF in disequilibrium with VEGF, causes a switch from neovascularization to fibrosis, an event known as angiofibrotic switch, which promotes scarring of the retina [100]. Synergistically with TGF $\beta$, CTGF causes cellular changes (myofibroblastic phenotype) and changes in extra-cellular matrix in myopia and glaucoma [101]. In glaucoma, pre-treatment of human cribrosa cells with anti-CTGF antibody FG3019/pamrevlumab, reduced CTGF-induced ECMassociated gene expression (fibronectin, fibrillin-1, CTGF, collagen 1, and $\alpha$-smooth muscle actin) [102] . In a mouse model of diet-induced insulin-resistant diabetes, elevated levels of CTGF in the brain were detected and correlated with the clinical progression of Alzheimer's disease [103]. In Duchenne muscular dystrophy (DMD), elevated levels of CTGF in animal models and biopsies of patients correlate with inflammation and fibrosis and with clinical severity of this disease [104-107]. In addition to a role for TGF $\beta$, [108], YAP/TAZ/TEAD and, subsequently, CTGF are elevated in human and mouse failing hearts [109]. In these pathologies, transcription factors Smad3 and SP1/SP3 are important in regulation of CTGF in response to TGF $\beta$ stimulation in myoblasts [26]. In skeletal muscle cells, CTGF causes increased accumulation of ECM through ERK phosphorylation possibly via the interaction with HSPGs since the addition of heparan could reverse CTGF effects [110]. Finally, treating dystrophic mice with the aforementioned FG-3019/pamrevlumab could ameliorate impaired muscle function and fibrosis, and a clinical trial for this treatment in DMD patients has been started (clinical trial: NCT02606136) [111].

\section{Systemic sclerosis}

Systemic sclerosis (SSc) is an autoimmune disease characterized by progressive fibrosis of skin and internal organs. Although the underlying mechanisms of the disease remain largely unknown, CTGF, may play an important role, since a polymorphism in the CTGF promoter region (rs6918698) that enhances CTGF and subsequent collagen I production was associated with systemic manifestation of the disease, and increased levels of CTGF in serum of patients with SSc correlate with the progression of skin and pulmonary fibrosis $[112,113]$. A later study in an animal model demonstrated that the synergic effect of CTGF and basic fibroblast growth factor contributes to skin fibrosis by increasing the levels of monocyte chemoattractant protein, which is important for infiltration of macrophages [114]. The role of CTGF in SSc fibroblasts is reported to be dependent on TGF $\beta$ and together, TGF $\beta$ and CTGF (induced by TGF $\beta$ ) cause persistent fibrosis in animal models of SSc [115]. Moreover, other evidence suggests that CTGF, TGF $\beta$ and endothelin-1 (ET-1) together induce myofibroblast differentiation [116]. It has recently been demonstrated that blocking CTGF by FG-3019/pamrevlumab antibody in mouse skin fibroblasts attenuates inflammation, fibrosis and vascular damage induced by angiotensin II [117]. Although direct blockade of CTGF seems to be a promising treatment option of SSc, additional studies have suggested that indirect modification of CTGF expression with the help of other potential therapeutic targets such as phosphatase and tension homolog (PTEN) and P2X purinoceptor 7 is a valid alternative approach $[118,119]$. In SSc skin fibroblasts, PTEN, a protein and lipid phosphatase and the inhibitor of PI3-Akt signaling, is downregulated and CTGF is important in the fibrosis induced by loss of PTEN. PTEN is also reduced in the fibroblasts of patients with idiopathic pulmonary fibrosis, leading to the hypothesis that it is also involved in lung fibrosis. This hypothesis was further tested by the genetic deletion of this gene together with CTGF in collagen expressing murine fibroblasts. These cells did not develop significant collagen deposition, highlighting the regulatory effect of CTGF downstream of PTEN [118].

\section{Lung fibrosis}

Idiopathic pulmonary fibrosis (IPF) is a progressive fibrotic condition of the lung with yet unknown etiology. The gradual loss of lung function can only be treated 
with lung transplantation, highlighting the necessity of finding other treatment options for this disease.

Although the etiology of the disease is not known, injury to the lung alveolar epithelial cells seems to be the primary event which results in excessive ECM disposition and fibrosis due to the imbalance between the profibrotic and antifibrotic events [120].

Increase of CTGF levels in fibroblasts of bleomycininduced mouse model of fibrosis indicates a potential role of CTGF in pathology of IPF [121]. CTGFdeficient animals have less myofibroblasts and ECM disposition, indicating that CTGF is necessary for induction of fibrosis in these animals [122]. However, histological analyses of the skin lesions of bleomycininduced pulmonary fibrosis animals demonstrate that CTGF induces the most severe fibrotic effects when administered with TGF $\beta$ [123]. Moreover, in the lungs of fibrosis-resistant mice, stimulation of fibrosis with bleomycin and CTGF together, and not each individually, causes fibrotic responses [124]. Therefore, CTGF seems to stimulate lung fibrosis in function of a second trigger, such as bleomycin and thus could be targeted to ameliorate fibrosis. Indeed, administration of anti-CTGF antibodies in several animal models of fibrosis reduces the expression of ECM components, enhances the survival after inducing lung damage by radiation and preserves the morphology of alveolar epithelial cells $[125,126]$.

In patients with IPF, CTGF is shown to be increased in fibroblasts [127], bronchoalveolar lavage cells [128], plasma [129] and lung tissue [130] which makes CTGF a valid therapeutic target and possible biomarker for companion diagnostics for treatment of this disease. There is encouraging evidence for the potential of antiCTGF monoclonal antibody, FG-3109/pamrevlumab, in treatment of IPF. In an open-label phase 2 trial, FG3109/pamrevlumab was proven to be safe and welltolerated by patients [131]. A double-blind placebocontrolled trial demonstrated significantly reduced decline of the forced vital capacity in patients treated with FG-3109/pamrevlumab compared to the placebo arm. Moreover, combining FG-3109/pamrevlumab with stable doses of pirfenidone, a TGF $\beta$ suppressor [132] and nintedanib, a TK inhibitor [133], was also welltolerated by IPF patients [134].

\section{Cardiac fibrosis}

Cardiac fibrosis often occurs in the context of hypertension and diabetes mellitus. Cardiac fibrosis is a huge global burden with limited treatment options, highlighting the importance of discovering new treatment options [135].

CTGF is expressed in cardiac fibroblasts and cardiomyocytes, where its promoter activity and expression is enhanced by TGF $\beta$. Increased CTGF causes upregulation of ECM proteins including fibronectin and collagen I and III following myocardial infarction in animals [136] and both TGF $\beta$ and CTGF were found to be expressed in fibroblasts of the scar tissue in a mouse myocardial infarction model [137]. CTGF is also involved in diabetic heart disease; it exerts an endocrine regulatory role on rat cardiomyocytes treated with high glucose and fatty acids. CTGF in these cells induces apoptosis and hypertrophy by phosphorylating the TK A receptor [138].

Blocking CTGF by $R N A$ interference in primary mouse cardiomyocytes causes attenuation of the expression of several genes such as stretch-induced chemokine, matrix metalloproteases, extracellular and cell-adhesion proteins, suggesting the involvement of CTGF in various pathways [139]. Ubiquitous or heart-specific CTGF knockdown or overexpression in mouse models of cardiac fibrosis did not significantly impact the progression of fibrosis, suggesting other possible drivers of cardiac fibrosis [140,141]. Conversely, CTGF overexpression in the myocardium of mice has also been observed to improve the left ventricular function after myocardial infarction through inhibition of inflammatory responses and apoptosis. Consistently, improved heart function in patients with elevated serum CTGF levels suggested that CTGF might indeed have some protective role in left ventricular remodeling after myocardial infarction [142].

A number of different in vivo interventions have linked CTGF with important molecular pathways of cardiac fibrosis. Cardiac-specific overexpression of serum response factor (SRF), acts as the upstream inducer of CTGF by reducing mi-RNA-133, which in turn downregulates both SRF and CTGF [27]. Moreover, circular RNA 000203 increased CTGF expression in mouse diabetic cardiomyopathy by inhibiting miR-26b$5 p$, which attenuates fibrosis by downregulating CTGF [143]. MiR-455 and -132 are still other mi-RNAs recently reported to attenuate fibrosis by decreasing CTGF and offering new potential drug targets [144,145].

As for targeting CTGF for treatment of heart disease, administration of the human IgG CTGFneutralizing antibody FG-3019/pamrevlumab for two weeks in the lamin A/C-deficiency mouse model of cardiomyopathy, significantly improved cardiac fibrosis and enhanced left ventricular function [146]. A similar protective effect was observed for the rodent equivalent FG-3149 in the PKCE mouse model of dilated cardiomyopathy [147]. Thus far, CTGF inhibition for treatment of heart diseases has not been studied in clinical trials.

\section{Liver fibrosis}

Although the liver parenchyma has a large regenerative capacity, chronic liver disease can lead to the permanent loss of hepatocyte mass and replacement by fibrotic tissue. This can ultimately lead to severe architectural disturbance called cirrhosis, which is associated with complications such as malnutrition, 
portal hypertension, gastrointestinal bleeding, ascites, hepatorenal syndrome and encephalopathy, eventually resulting in the need for a liver transplantation. The underlying causes of cirrhosis worldwide are diverse, but viral hepatitis (around 60\%) and chronic alcohol abuse (around $20 \%$ of the etiology) are important factors [148]. The histopathological features of cirrhosis include diffuse hepatic fibrosis with the formation of

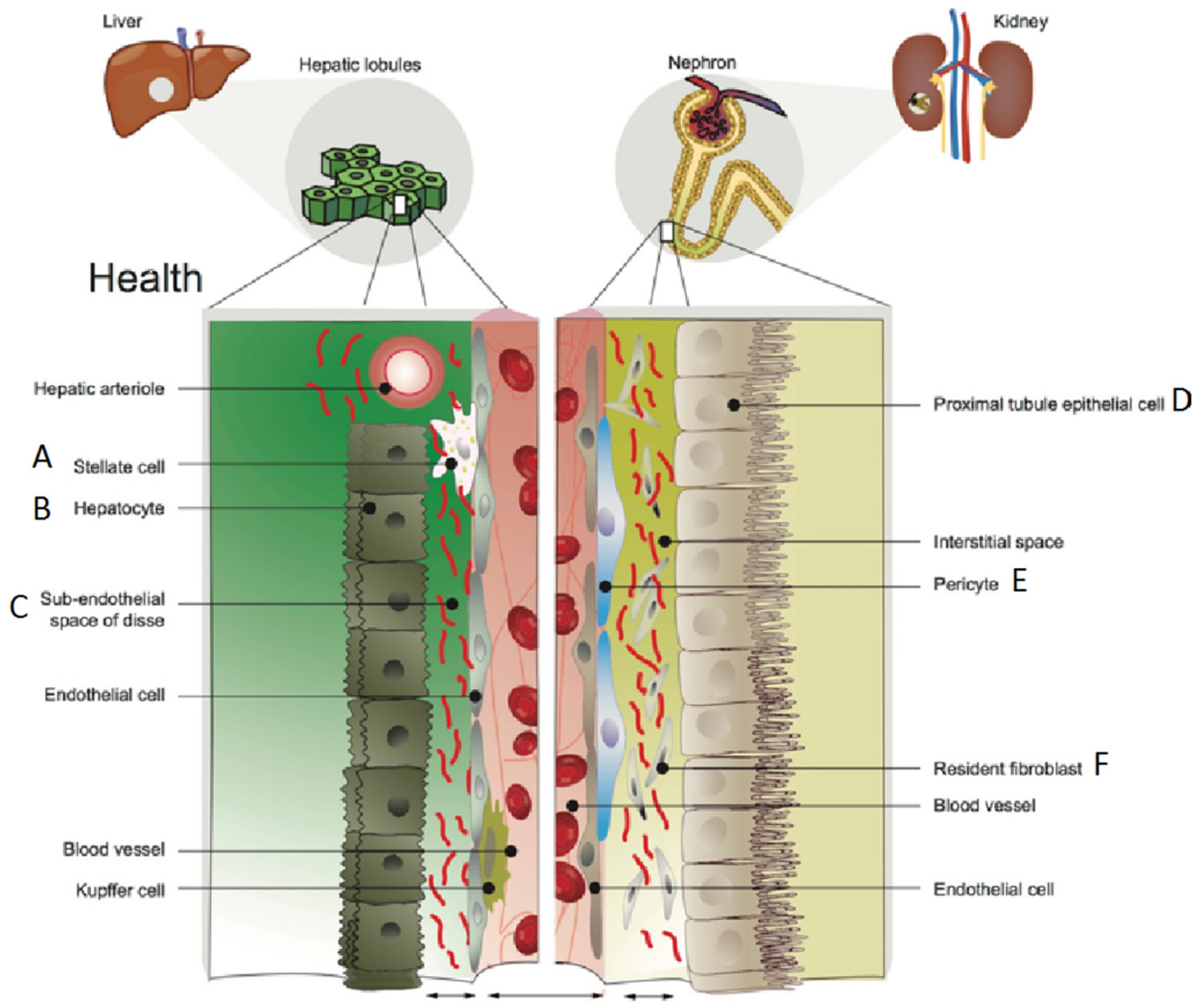

Fibrosis

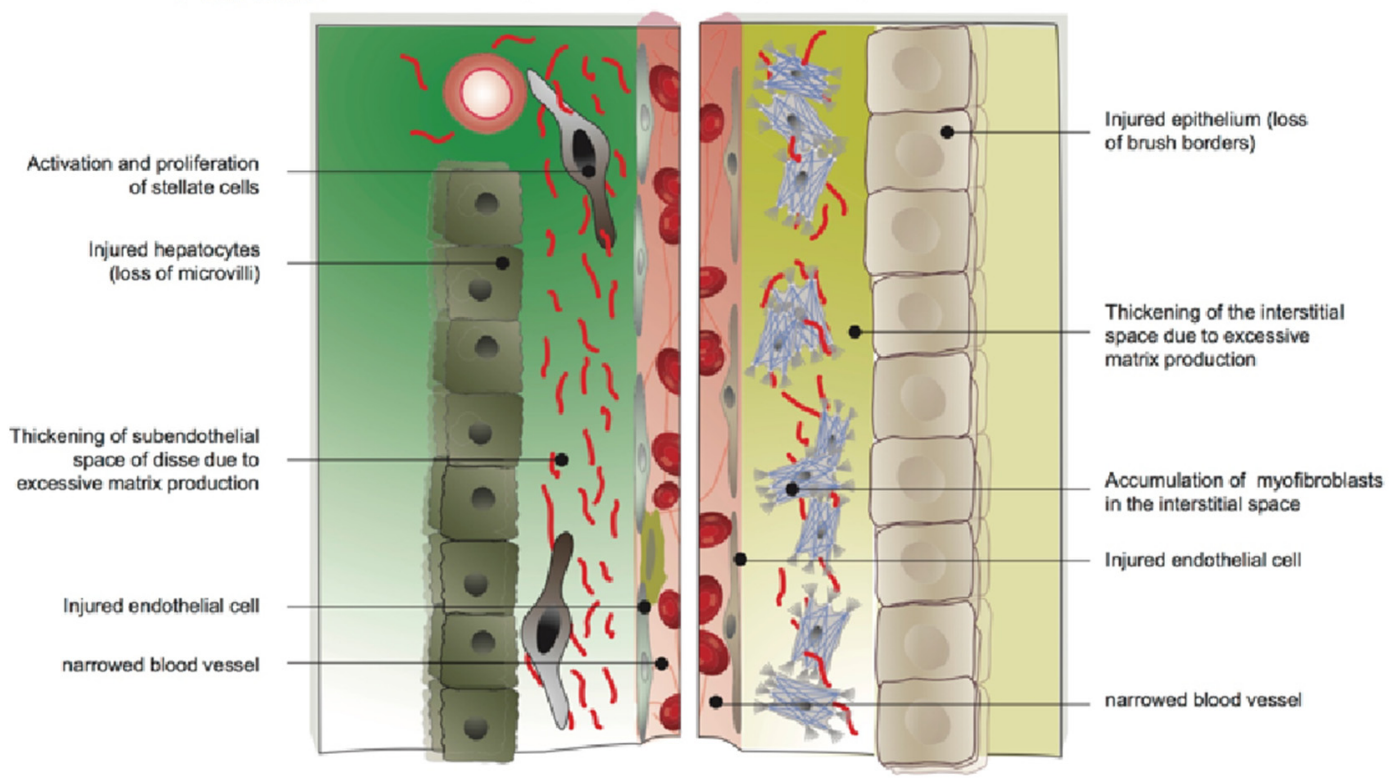

Fig. 4 (legend on next page) 
nodules of regenerating hepatocytes. The increasing degree of connective tissue deposition results in destruction of the normal liver architecture, with an increased and altered composition of the cellular matrix of the subendothelial space of Disse, generating additional diffusion barriers between hepatocytes and liver sinusoids and an increased resistance for the portal blood flow.

Hepatic stellate cells (HSCs), which are pericytes situated in the perisinusoidal space in close contact with the endothelium and hepatocytes, are considered the primary source of ECM deposition. During normal physiology, HSCs are involved in vitamin A and fat storage and constitute circa $10-15 \%$ of cells in the liver [149]. In addition, it has been shown that stellate cells also play a central role in liver regeneration/repair, angiogenesis, vascular remodeling and the hepatic immune response through their ability to act as antigen presenting cells [150]. As a result of hepatocellular damage characterized by apoptosis, oxidative stress and the release of cytokines and growth factors by nonparenchymal liver cells (granulocytes and macrophages), HSCs are activated and start to proliferate, transform into myofibroblasts, migrate, contract and bring about fibrogenesis. However, stellate cells are not the only cell type involved in liver fibrosis. Depending on the underlying etiology also portal (myo)fibroblasts, circulating fibrocytes, hepatocyte progenitor cells, bone marrow derived cells, Kupffer cells and even endothelial cells (through epithelial to mesenchymal transition) are believed to function as fibrogenic cells (Fig. 4) [150,151].

HSC activation occurs in different stages of liver disease [149]. As already mentioned, the initiation is brought about by paracrine activation of stellate cells due to the release of cytokines by apoptotic hepatocytes. The stimulated HSCs are further activated by cytokines produced by invading leucocytes, thrombocytes, activated Kupffer cells and local hepatocytes. In addition, a progressive change in the constituents and density of the surrounding ECM occurs within the subendothelial space towards an environment con- taining more fibril-forming collagens (particularly collagen type I and III) and fibronectin through the action of sinusoidal endothelial cells that are stimulated by TGF $\beta[152,153]$ (Fig. 4). This altered ECM composition gives rise to several feedback mechanisms that further stimulate the fibrosis process.

Although a lot of attention has gone to TGF $\beta$, CTGF is another important and partially TGF $\beta$ independent profibrotic stimulus in liver fibrosis. The range of actions of CTGF in liver fibrosis is broad and includes increased cell proliferation, differentiation, migration, adhesion, ECM synthesis, and direct interaction with matrix components [154]. Several studies have demonstrated that CTGF is overexpressed in fibrotic livers [155]. However, the cellular distribution of CTGF expression appears to be dependent on disease etiology and progression [151]. Again HSCs (together with fibroblast) are considered the most important source of CTGF in liver fibrosis, while also hepatocytes, portal fibroblasts and cholangiocytes can contribute to CTGF production $[156,157]$. Although TGF $\beta$ signaling results in increased CTGF expression through Smad signaling pathways in hepatocytes, CTGF expression in HSCs occurs through both TGF $\beta$ dependent (via Smad3 and Stat3 signaling) and TGF $\beta$ independent pathways $[158,159]$. Like hepatocytes, hepatocyte progenitor cells have also been demonstrated to contribute to CTGF production in response to TGF $\beta$ through Smad signaling pathways [160]. Next to TGF $\beta$, hepatic expression levels of CTGF can be upregulated by ET-1, TNFa, glucocorticoids, VEGF, acetaldehyde, nitrogen oxide, thrombin, lipid peroxidation products, PDGF, p53, hypoxia and mechanical factors such as shear and cell stretch $[151,161]$.

While CTGF antagonizes BMP, it stimulates TGF $\beta$ signaling [68] and promotes the phenotypic changes of HSC into myofibroblast and in addition, regulates collagen I and integrin expression in HSC and supports adhesion via interaction of a CTGF surface receptor with fibronectin and HSPGs [167-169]. On the other side, PPARy, curcumin and microRNA-214 have been shown to downregulate CTGF expression in HSCs and

Fig. 4. Liver and kidney fibrosis as two examples of CTGF-related adverse tissue remodeling. Liver: cytokines and growth factors including CTGF are secreted upon injury from hepatocytes and inflammatory cells. CTGF is involved in the following phenomena: A) CTGF produced continuously by the HSCs, in cooperation with TGF $\beta$ and fibronectin, mediate the proliferation, survival, migration and adhesion of the HSCs. B) Hepatocytes go through epithelial to mesenchymal transition (EMT) which contributes to the pool of myofibroblasts that produce ECM and bring about fibrogenesis. EMT is induced by TGF $\beta$ and inhibited by BMP7. CTGF as the downstream inducer of TGF $\beta$, shifts the ratio of TGF $\beta / B M P 7$ towards more EMT. C) Sustained production of CTGF in HSCs is responsible for fibrillary collagen production and thickening of the subendothelial space of Disse due to excessive matrix production [149,162]. Kidney: in response to injury, recruited inflammatory cells and the injured epithelial cells, produce CTGF and other profibrotic cytokines. CTGF is involved in the following phenomenon: D) Proximal tubule epithelial cells as a result of production of CTGF and through EMT, dedifferentiate to myofibroblasts. Although there is a controversy as to the contribution of EMT to ECM-producing mesenchymal cells, using BMP7 agonists, TGF $\beta$ and CTGF antibodies, inhibits EMT and points to involvement of these pathways in the latter. E) Pericytes, in response to CTGF (among others including TGF $\beta$ and PDGF), are stimulated to detach from the tubular basement membrane, migrate into the interstitial space and differentiate to myofibroblasts. $F$ ) Resident fibroblasts in response to increasing levels of CTGF, turn into pathological fibroblasts that contribute significantly to the production of ECM [163-166]. 
nearby hepatocytes [50,170-172]. As mentioned before, the liver also plays a role in the clearance of circulating CTGF through LRP1 receptor-mediated endocytosis by hepatocytes [173].

Due to its downstream localization in different pathways leading to fibrosis, CTGF may be an attractive target for anti-fibrotic therapies in liver fibrosis. Indeed, downregulation of CTGF expression with the help of siRNA has been demonstrated to reduce liver fibrosis in rodent models [174-176]. Other drugs that inhibit CTGF expression through PPARy and protein kinase A activity such as prostaglandin E2, prostaglandin J2 and pentoxifylline have been shown to attenuate fibrosis in experimental and clinical settings [177-179]. In 2016, a phase 2 study with the humanized antiCTGF antibody FG-3019/pamrevlumab in patients with liver fibrosis was completed whose results are yet awaited (NCT01217632).

The secretory character of CTGF and its production by various cell types in liver disease makes it a potential biomarker for the diagnosis of liver fibrosis and its progression. Several clinical studies have demonstrated significantly increased serum or plasma CTGF in patients with fibrotic/cirrhotic liver disease. However, CTGF levels did not correlate with the stage of fibrosis, and appeared to be higher in patients with progressive fibrosis than in those with end-stage cirrhotic liver disease [149,151,180].

\section{Kidney fibrosis}

Kidney fibrosis is a final common pathway of chronic kidney disease (CKD) irrespective of etiology [181]. CKD is an important problem for patients, doctors and health administrators. An estimated $10 \%$ of the global population suffers from CKD and over 2 million people with an advanced stage of CKD currently receive renal replacement therapy (RRT). However, RRT delivery is not widely available, i.e. predominantly in the more economically developed countries. Unfortunately, for many patients in the rest of the world, the proper care for severe renal failure is still lacking. In addition, the number of people with CKD worldwide is rapidly rising and this is considered a global health crisis. Therefore, it is necessary to counteract kidney fibrosis in progressive kidney diseases before the point of irreversibility.

In the kidneys, tubular epithelial cells are the most vulnerable cell type to injury, but still, the excessive deposition of ECM in the interstitial compartment, which leads to scar tissue formation, is produced by myofibroblasts (Fig. 4). Upon injury, tubule epithelial cells may undergo a partial epithelial-to-mesenchymal transition (EMT) which results in tubular function impairment, triggers cell cycle arrest and promotes the release of critical fibrogenic cytokines [182] and growth factors such as CTGF.

Besides its direct action and as a co-factor for TGF $\beta$, CTGF also has the potential to modulate VEGF and
BMPs, which are integral to development and repair processes in renal fibrogenesis [183]. The mechanism of action of CTGF in renal fibrosis has been widely reviewed by others $[84,182,183]$. In brief, CTGF is necessary for induction of TGF $\beta$ and, apart from that, exerts profibrotic effects by interacting with lowdensity lipoprotein receptor-related protein 6 (LRP6), activating the Wnt pathway and enhancing insulin growth factor and collagen expression [184]. Recently, it has been suggested that overexpression of CTGF after ureteral obstruction in mouse kidney, increases inflammation and fibrosis but does not affect nephrogenesis or kidney homeostasis. Also, the apparent lack of any renal dysfunction in the CTGF conditional knockouts is consistent with an aspecific role of CTGF largely restricted to modulating a tissue injury response [185]. In the same study, authors showed that pericytes isolated from mice overexpressing CTGF became hyper-migratory and hyperproliferative. Treatment with recombinant domain 1, 1 +2 (-N terminus), or 4 (-C terminus) independently activated myofibroblast differentiation and woundhealing responses in these pericytes. CTGF domain 4 showed the broadest profibrotic activity. Administration of blocking antibodies specifically against CTGF domain 4 or recombinant Dickkopf-related protein-1, an endogenous inhibitor of LRP6, effectively inhibited inflammation and fibrosis associated with ureteral obstruction in vivo, pointing to CTGF domain 4 as a therapeutic target in renal fibrosis [185].

Another therapeutic strategy for renal fibrosis is to reduce fibroblast proliferation. Lysophosphatidic acid (LPA) signaling through its receptor LPA1 directly induced fibroblasts recruitment. In a LPA1-deficient (LPA1-/-) or -sufficient (LPA1+/+) mouse model, CTGF expression in tubule epithelial cells was suppressed [186]. CTGF derived from proximal tubule epithelial cells (PTC) mediated both renal fibroblast proliferation and myofibroblast differentiation. Moreover, it was shown that LPA-LPA1 signaling directly induced CTGF expression in primary PTC, through a myocardin-related transcription factor (MRTF)-serum response factor (SRF) pathway. Administration of an inhibitor of this factor suppressed renal fibrosis in these cells. The authors suggested that targeting LPA-LPA1 signaling and/or MRTF-SRF-induced transcription could be a promising therapeutic strategy for renal fibrosis [186].

Another group showed the role of the protein Sirtuin 1 (Sirt1) in the protection against renal disease by inhibiting fibrosis and oxidative metabolism. In this study, the role of a Sirt1 activator, SRT1720 was investigated in unilateral ureteral obstruction (UUO)induced tubulointerstitial fibrosis in mice. The administration of SRT1720 increased the Sirt1 levels and partially attenuated both UUO-induced renal fibrosis and apoptosis. SRT1720 also attenuated the levels of oxidative stress suggesting its protective potential against reactive oxygen species-induced damage. In 
this context, SRT1720 effectively inhibited the levels of TGF $\beta / C T G F$ induced by UUO. Authors suggested that the mechanisms of action for SRT1720 may include, at least in part, the suppression of renal oxidative stress and the TGF $\beta / C T G F$ signaling pathway. Therefore, Sirt1 activator may be another candidate therapeutic agent for the treatment of fibrotic kidney disease via downregulation of CTGF [187].

Very recently, another role for CTGF has been suggested in fibrotic tissue remodeling. Prominent expression of CTGF and VEGF-C were associated to lymphangiogenesis during tubule-interstitial fibrosis in obstructed nephropathy [188]. Using a CTGF knockout mouse model, the authors observed significantly reduced number of lymphatic vessels and VEGF-C expression in comparison to wild-type mice. Also in an ischemia-reperfusion injury mouse model, CTGF knockdown was associated with reduced lymphangiogenesis.

In vitro, CTGF induced VEGF-C production in $\mathrm{HK}-2$ cells, while CTGF siRNA suppressed TGF $\beta$-induced VEGF-C upregulation. The authors used surface plasmon resonance analysis, which show that CTGF and VEGF-C directly interact, and that CTGF is highly involved in fibrosis-associated renal lymphangiogenesis through regulation of this direct interaction.

In glomerulonephritis, inhibition of CTGF seems to be fundamental, since its elevated expression leads to signaling of other growth factors and promotes fibrosis [188]. The investigators used 3 models of CTGF knockout mice to investigate the role and source of CTGF in anti-glomerular basement membrane glomerulonephritis and showed that macrophage migration into glomeruli with nephritis is mediated by CTGF derived from mesangial cells, which enhanced macrophage chemotaxis and adhesion in a CTGF-dependent manner. Systemic reduction of CTGF expression ameliorated proteinuria and glomerular injury in the mouse model of anti-glomerular basement membrane glomerulonephritis through suppression of inflammation and ECM accumulation [189]. Altogether, these very recent evidences of CTGF's role in fibrosis regulation in kidney demonstrate the urgency to efficiently reduce this signaling pathway in order to block renal fibrosis and improve kidney function upon injury.

\section{Diabetic nephropathy}

Diabetic nephropathy (DN) is one of the major causes of end-stage kidney disease for which dialysis or transplantation are the only treatment options [190]. The incidence of diabetes and subsequently diabetic nephropathy is increasing worldwide imposing a large burden on clinical care. CTGF has been associated with numerous diabetic complications, but it is of particular interest to diabetic nephropathy. Soon after its identification, the expression of CTGF $m R N A$ was shown to be strongly upregulated in human mesangial cells cultured under high glucose, and in kidney biopsies of patients with DN [191,192]. These observations were extended in rodent models of both type 1 and type 2 DN [193-195]. Furthermore, severity of DN was aggravated in transgenic mice with specific overexpression of CTGF in glomerular podocytes [196]. In kidney biopsies of patients [191] with type 2 DN, tubular expression of CTGF correlated with proteinuria, serum creatinine, and interstitial fibrosis [197]. Interestingly, overexpression of CTGF in human diabetic glomeruli was also associated with reduction in podocyte markers and decreased signaling activity of BMP [198], both of which are both important elements of DN. These data suggest that CTGF is a pathogenic factor in the development and progression of DN.

Upregulation of CTGF expression was also observed in the diabetic myocardium, liver, retina, and aorta [194,199-201]. In addition, soluble CTGF levels were elevated in the vitreous of patients with diabetic retinopathy [202]. CTGF levels were also increased in plasma and urine of patients with DN and plasma CTGF was shown to be an independent predictor of end-stage renal disease in patients with DN, proving its promising potential as a biomarker in diabetic patients [203,204].

Various studies have investigated the role of CTGF as a target for therapy in diabetes. In mouse models of type 1 and type 2 DN, treatment with CTGF antisense oligodeoxynucleotides proved to be successful in attenuation of proteinuria, and in reduction of genes involved in mesangial matrix expansion [205]. Similar observations were seen in diabetic mice lacking one CTGF allele [206] and in diabetic mice treated with an antibody against CTGF [207]. In these two latter studies, the attenuation of DN by inhibition of CTGF was associated with preserved BMP signaling and decreased $\beta$-catenin expression. Moreover, although Dendooven et al. and Patel et al. did not find a correlation between the -945 GC SNP (rs6918698, associated with pulmonary disease in SSc and affecting SP1 binding to the CTGF promoter) with nephropathy or outcome in type 1 diabetic patients, or with cardiac and kidney complications in type 2 diabetic patients [208,209], Wang et al. found that another -20 GC SNP in the promoter of CTGF enhances the relative risk of microalbuminuria in diabetic patients up to three-fold and also increases the risk of developing diabetic nephropathy. This polymorphism is located at the Smad1-binding domain of CTGF promoter and is actively involved in Smad1 regulation of basal CTGF transcription [210]. Altogether this data emphasizes the important direct role of CTGF in DN as well as its regulatory effects on the implicated growth factors and signaling pathways.

Treatment with the monoclonal anti-CTGF antibody FG-3019/pamrevlumab has also been found to be safe for human patients. FG-3019/pamrevlumab therapy may reduce urinary albumin excretion in 
patients with diabetes [211]. However, many larger trials would be needed before clinical implication can be considered.

\section{Solid organ transplantation}

Allograft fibrosis is a multifactorial phenomenon which limits the graft survival in all solid organ transplantations. Ischemic reperfusion injury, infections, calcineurin inhibitors and acute rejection are some of the initial insults to the allografts leading to fibrosis [212]. Apart from the initial insults, chronic rejection following organ transplantation also induces loss of allograft function. It was shown that TGF $\beta$ and CTGF were expressed in cardiac allografts of mice with chronic rejection but were not expressed in grafts without it [213]. TGF $\beta$ transfection of syngeneic grafts did not result in CTGF expression or chronic rejection. This indicates that TGF $\beta$ alone is not sufficient to induce chronic rejection, and that CTGF is required. The authors suggested that CTGF might serve as a therapeutic target for organ chronic rejection.

Both in vitro studies [214] and mouse renal allografts [215] show that CTGF expression by renal tubule epithelial cells is a key mediator of TGF $\beta$-dependent interstitial fibrogenesis. Urinary CTGF concentrations were higher in the presence of interstitial fibrosis in concurrent human renal allograft biopsies. It has been demonstrated that urinary CTGF concentrations were higher in the presence of interstitial fibrosis in concurrent human renal allograft biopsies [216]. Very recently, in a retrospective cohort analysis of 160 kidney transplant recipients with paired protocol renal biopsies, tubule-interstitial expression and urinary excretion of CTGF at 3 months after renal transplantation together with donor age predicted progression of interstitial fibrosis and tubular atrophy before any functional deterioration of allografts 5 years after transplantation [217].

\section{Clinical and translational aspects}

There is an ongoing quest for identification of biomarkers for fibrosis in different disease contexts. There are some successful studies pointing towards CTGF as a potential biomarker. For instance, the urinary and interstitial CTGF can predict the evolution of histological damage in renal transplant recipients [217]. However, given the complex and contextdependent nature of fibrosis, measuring CTGF in all disease settings might not be so straightforward. CTGF undergoes glomerular filtration, tubular reabsorption (almost complete under normal circumstances) and can be produced by tubular epithelial cells, immune cells and mesangial cells (including fibroblasts). The presence of CTGF in urine can therefore reflect (1) intrarenal production, (2) tubular dysfunction and (3) saturation of tubular reabsorption, resulting from increased filtration (glomerular damage) or from high plasma concentrations [124]. Therefore, there exists a potential benefit in the identification of markers directly linked to increased CTGF. One possible candidate is autotoxins, which have attracted the attention of researchers and pharmaceutical companies. One of these autotoxins is phospholipid lysophosphatidic acid (LPA), which is involved in liver, kidney and pulmonary fibrosis, and directly induces CTGF expression [242]. For example, in a radiation-induced model of lung fibrosis, LPA stimulated fibroblast proliferation, and inhibiting CTGF reversed this effect. Moreover, VPC12249, a LPA receptor 1/3 antagonist, decreases CTGF and TGF $\beta$ production in animals and reduces fibroblast pool and matrix deposition [243]. In an animal model of renal fibrosis, the proximal tubule epithelial cell-produced CTGF induced accumulation of fibroblasts and differentiation of myofibroblasts. They also showed that LPA signaling directly induces CTGF in renal proximal tubule cells through signaling pathways that comprise Ga12/13, Rho, Rho-associated protein kinase (ROCK) and actin polymerization [186]. In these pathologies, inhibition of LPA seems to be a valid therapeutic option. Galapagos has developed a first-in class autotoxin inhibitor GLPG1690 [244] which was evaluated in a randomized, double-blind, placebocontrolled study in subjects with IPF (clinical trial number NCT0273880). The results of the study are favorable for treatment of these patients and might suggest a novel therapeutic option in other disease settings where similar pathological pathways are involved.

The most advanced trials with an anti-CTGF agent have been performed with FG-3019/pamrevlumab for IPF, which was discussed earlier, and this compound is currently tested in clinical trials for muscular dystrophy and pancreatic cancer as well. These studies exemplify successful treatments for fibrosis via CTGF targeting, and could be extrapolated to other disease contexts by conducting additional clinical trials.

\section{Conclusions and future directions}

CTGF is one of the best-studied factors in fibrosis and, across different pathologies, it has strong potential as a diagnostic, prognostic and therapeutic biomarker. However, given the complex nature of tissue fibrosis in different organs and conditions, a composite panel of markers might be needed. The current interest in discovering new pathways also includes epigenetic mechanisms. For example, DNA methylation, histone modifications and mi-RNA effects makes them attractive therapeutic targets [245]. For instance the mi-RNA-29 family is involved in heart, lung, kidney and liver fibrosis and is an interesting target to be studied in different fibrosis models [246]. RXi Pharmaceuticals have launched 2 phase 1 clinical trials (NCT01780077 and NCT01640912) that show 
safety, tolerability and proof of concept of their and phase 2 clinical trials for this compound are in progress.

In conclusion, despite existing pitfalls and challenges in the field, fundamental and clinical advances in research have provided a number of promising treatment approaches for tissue fibrosis. However, it is important to remember that future approaches should also address the specific genetic makeups of patients in responding to anti-fibrotic medications. This requires integrated approaches that take into consideration both fundamental and translational research trajectories that collaborate with the aim of discovering new fibrosis pathways and tailoring treatments to patients' specific medical needs.

\section{Funding sources}

YR was supported by strategic basic Fonds Wetenschappelijk Onderzoek (FWO) [grant number $1 \mathrm{~S} 24417 \mathrm{~N}]$.

\section{Acknowledgement}

We sincerely thank Kurt Buhler from the laboratory of 'Behavioral and Developmental Genetics', KU Leuven, for his helpful text corrections. We would also like to express our sincere gratitude to Mr. Albert Herelixka, laboratory of 'Nephrology', KU Leuven for kindly drawing Fig. 4.

Received 20 December 2017; Received in revised form 5 March 2018; Accepted 6 March 2018 Available online $x x x x$

Keywords: Connective tissue growth factor; CCN2;

Matricellular protein; Fibrosis;

Marker and therapeutic target compound that targets CTGF-regulating mi-RNA

Duchenne muscular dystrophy; DN, diabetic nephropathy; ECM, extracellular matrix; EGF, epidermal growth factor; EGFR, epidermal growth factor receptor; EMT, epithelialto-mesenchymal transition; ET-1, endothelin-1; Ets1, ETS proto-oncogene 1; FAK, focal adhesion kinase; FGF-2, fibroblast growth factor 2; FGFB, fibroblast growth factor

2; FOXO1/3a, forkhead box protein O1/forkhead box protein O3a; FZD7, frizzled 7; HIF1a, hypoxia-inducible

factor 1 $\alpha$; HSC, hepatic stellate cell; HSPGs, heparan sulfate protoglycans; IGF, insulin-like growth factor; IL-1R, interleukin 1 receptor; IL1 $\beta$, interleukin $1 \beta$; IPF, idiopathic pulmonary fibrosis; ITGs, integrins; ITG $\beta 1$, integrin $\alpha 3 / \beta 1$; JAK2, Janus kinase 2; LPA, lysophosphatidic acid; LRP1, low-density lipoprotein receptor-related protein 1; LRPS, lipoprotein receptor related proteins; MAPK, mitogen activated protein kinase; MCP, monocyte chemoattractant protein; MEK/ERK, mitogen-activated protein kinase kinase/extracellular signal-regulated kinase; Mi-RNA, micro RNA; MMP2, matrix metalloprotease 2; MMP3, matrix metalloprotease 3; MMPs, matrix metalloproteases;

MPK1, mitogen activated protein kinase (MAPK) phosphatase 1; NFk-B, nuclear factor kappa-light-chainenhancer of activated B cell; NK, c-Jun N-terminal kinase; NOV, nephroblastoma overexpressed protein; PAR1, protease-activated receptor 1; PDGF, platelet-derived growth factor; PDGFB, platelet-derived growth factor B; PPAR, peroxisome proliferator-activated receptor; PTEN, phosphatase and tension homolog; Rac1, Ras-related C3 botulinum toxin substrate; RAS-GTP, RAS-guanosine triphosphate; ROCK, Rho-associated protein kinase; ROS, reactive oxygen species; RP6, low-density lipoprotein receptor-related protein 6; RRT, renal replacement therapy; RTK, receptor tyrosine kinase; Sirt1, Sirtuin 1; SP1/SP3, specificity protein 1/specificity protein 3; SRF, serum response factor; SSc, systemic sclerosis; STAT3, signal transducer and activator of transcription 3; TAK1, transforming growth factor beta-activated kinase 1; TAZ, transcriptional coactivator with PDZ-binding motif; TEAD, transcriptional enhancer factor TEF-1; TGF $\beta$, transforming growth factor $\beta$; TGF $\beta R$, transforming growth factor $\beta$ receptor; TGs, integrins; TK, tyrosine kinase; TNF, tumor necrosis factor; TNF- $\alpha$, tumor necrosis factor $\alpha$; TNFR, tumor necrosis factor receptor; UUO, unilateral ureteral obstruction; UV, ultra violet; VEGF, vascular endothelial growth factor; VEGFs, vascular endothelial growth factors; VWF, von Willebrand factor type C; YAP, yesassociated protein.

\section{References}

AP1, activator protein 1; ASK1, apoptosis signalregulating kinase 1; AT1R, angiotensin 2 type 1 receptor; AT2R, angiotensin 2 type 2 receptor; BCL-2, B-cell lymphoma 2; BMP4, bone morphogenic protein 4; BMP7, bone morphogenic protein 7; BMPs, bone morphogenic proteins; cAMP, cyclic adenosine monophosphate; CKD, chronic kidney disease; CTGF, connective tissue growth factor; CYR61, cysteine rich angiogenic inducer 61; c-Src, proto-oncogene c; DDR, DNA damage repair; DMD,
[1] Z. Ungvari, M.N. Valcarcel-Ares, S. Tarantini, A. Yabluchanskiy, G.A. Fulop, T. Kiss, et al., Connective tissue growth factor (CTGF) in age-related vascular pathologies, Geroscience 39 (2017) 491-498.

[2] K.P. Holbourn, K.R. Acharya, B. Perbal, The CCN family of proteins: structure-function relationships, Trends Biochem. Sci. 33 (2008) 461-473. 
[3] S.C. Barreto, A. Ray, P. Ag Edgar, Biological characteristics of CCN proteins in tumor development, J. BUON 21 (2016) 1359-1367.

[4] J.I. Jun, L.F. Lau, Taking aim at the extracellular matrix: CCN proteins as emerging therapeutic targets, Nat. Rev. Drug Discov. 10 (2011) 945-963.

[5] M.D. Welch, M. Howlett, H.M. Halse, W.K. Greene, U.R. Kees, Novel CT domain-encoding splice forms of CTGF/ CCN2 are expressed in B-lineage acute lymphoblastic leukaemia, Leuk. Res. 39 (2015) 913-920.

[6] D.M. Bradham, A. Igarashi, R.L. Potter, G.R. Grotendorst, Connective tissue growth factor: a cysteine-rich mitogen secreted by human vascular endothelial cells is related to the SRC-induced immediate early gene product CEF-10, J. Cell Biol. 114 (1991) 1285-1294.

[7] A. Igarashi, H. Okochi, D.M. Bradham, G.R. Grotendorst, Regulation of connective tissue growth factor gene expression in human skin fibroblasts and during wound repair, Mol. Biol. Cell 4 (1993) 637-645.

[8] M. Uhlen, L. Fagerberg, B.M. Hallstrom, C. Lindskog, P. Oksvold, A. Mardinoglu, et al., Tissue-based map of the human proteome, Science 347 (2015) 1-9.

[9] S. Kubota, M. Takigawa, Cellular and molecular actions of CCN2/CTGF and its role under physiological and pathological conditions, Clin. Sci. (Lond.) 128 (2015) 181-196.

[10] F.A. Mendes, J.M. Coelho Aguiar, S.A. Kahn, A.H. Reis, L. G. Dubois, L.F. Romao, et al., Connective tissue growth factor (CTGF/CCN2) induces astrogenesis and fibronectin expression of embryonic neural cells in vitro, PLoS One 10 (2015) 1-18.

[11] X. Xue, Q. Chen, G. Zhao, J.Y. Zhao, Z. Duan, P.S. Zheng, The overexpression of TGF- $\beta$ and CCN2 in intrauterine adhesions involves the NF-KB signaling pathway, PLoS One 10 (2015) 1-12.

[12] Y. Cho, R. Silverstein, M.T. Geisinger, S. Martinkovich, H. Corkill, J.M. Cunnick, et al., AFAP1 is a novel downstream mediator of TGF- $\beta 1$ for CCN2 induction in osteoblasts, PLoS One 10 (2015) 1-15.

[13] A. Holmes, D.J. Abraham, S. Sa, X. Shiwen, C.M. Black, A. Leask, CTGF and SMADs, maintenance of scleroderma phenotype is independent of SMAD signaling, J. Biol. Chem. 276 (2001) 10594-10601.

[14] V.K. Raghunathan, B. Dreier, J.T. Morgan, B.C. Tuyen, B. W. Rose, C.M. Reilly, et al., Involvement of YAP, TAZ and HSP90 in contact guidance and intercellular junction formation in corneal epithelial cells, PLoS One 9 (2014) $1-14$.

[15] F. Preisser, K. Giehl, M. Rehm, M. Goppelt-Struebe, Inhibitors of oxygen sensing prolyl hydroxylases regulate nuclear localization of the transcription factors Smad2 and YAP/TAZ involved in CTGF synthesis, Biochim. Biophys. Acta 1863 (2016) 2027-2036.

[16] A. Nagasawa-Masuda, K. Terai, Yap/Taz transcriptional activity is essential for vascular regression via Ctgf expression and actin polymerization, PLoS One 12 (2017) $1-23$.

[17] I. Mannaerts, S.B. Leite, S. Verhulst, S. Claerhout, N. Eysackers, L.F. Thoen, et al., The Hippo pathway effector YAP controls mouse hepatic stellate cell activation, J. Hepatol. 63 (2015) 679-688.

[18] S. Anorga, J.M. Overstreet, L.L. Falke, J. Tang, R.G. Goldschmeding, P.J. Higgins, et al., Deregulation of HippoTAZ pathway during renal injury confers a fibrotic maladaptive phenotype, FASEB J. 0 (2018) 1-18.
[19] R. Sherriff-Tadano, A. Ohta, F. Morito, M. Mitamura, Y. Haruta, S. Koarada, et al., Antifibrotic effects of hepatocyte growth factor on scleroderma fibroblasts and analysis of its mechanism, Mod. Rheumatol. 16 (2006) 364-371.

[20] J.P. Van Beek, L. Kennedy, J.S. Rockel, S.M. Bernier, A. Leask, The induction of CCN2 by TGFbeta1 involves Ets-1, Arthritis Res. Ther. 8 (2006) 1-9.

[21] J.S. Yordy, O. Moussa, H. Pei, D. Chaussabel, R. Li, D.K. Watson, SP100 inhibits ETS1 activity in primary endothelial cells, Oncogene 24 (2005) 916-931.

[22] S.S. Nakerakanti, B. Kapanadze, M. Yamasaki, M. Markiewicz, M. Trojanowska, Fli1 and Ets1 have distinct roles in connective tissue growth factor/CCN2 gene regulation and induction of the profibrotic gene program, J. Biol. Chem. 281 (2006) 25259-25269.

[23] M. Fujii, H. Nakanishi, T. Toyoda, I. Tanaka, Y. Kondo, H. Osada, et al., Convergent signaling in the regulation of connective tissue growth factor in malignant mesothelioma: TGFbeta signaling and defects in the Hippo signaling cascade, Cell Cycle 11 (2012) 3373-3379.

[24] R.A. Levine, A.A. Hagege, D.P. Judge, M. Padala, J.P. DalBianco, E. Aikawa, et al., Mitral valve disease-morphology and mechanisms, Nat. Rev. Cardiol. 12 (2015) 689-710.

[25] A. Leask, Integrin beta1: a mechanosignaling sensor essential for connective tissue deposition by fibroblasts, Adv. Wound Care (New Rochelle) 2 (2013) 160-166.

[26] G. Cordova, A. Rochard, C. Riquelme-Guzman, C. Cofre, D. Scherman, P. Bigey, et al., SMAD3 and SP1/SP3 transcription factors collaborate to regulate connective tissue growth factor gene expression in myoblasts in response to transforming growth factor beta, J. Cell. Biochem. 116 (2015) 1880-1887.

[27] A. Angelini, Z. Li, M. Mericskay, J.F. Decaux, Regulation of connective tissue growth factor and cardiac fibrosis by an SRF/MicroRNA-133a axis, PLoS One 10 (2015) 1-19.

[28] J. Dittmer, The role of the transcription factor Ets1 in carcinoma, Semin. Cancer Biol. 35 (2015) 20-38.

[29] J. Samarin, J. Wessel, I. Cicha, S. Kroening, C. Warnecke, M. Goppelt-Struebe, FoxO proteins mediate hypoxic induction of connective tissue growth factor in endothelial cells, J. Biol. Chem. 285 (2010) 4328-4336.

[30] L. Te Riet, J.H. van Esch, A.J. Roks, A.H. van den Meiracker, A.H. Danser, Hypertension: renin-angiotensin-aldosterone system alterations, Circ. Res. 116 (2015) 960-975.

[31] S. Guan, J. Zhou, Frizzled-7 mediates TGF-beta-induced pulmonary fibrosis by transmitting non-canonical Wnt signaling, Exp. Cell Res. 359 (2017) 226-234.

[32] C.M. Tran, Z.R. Schoepflin, D.Z. Markova, C.K. Kepler, D.G. Anderson, I.M. Shapiro, et al., CCN2 suppresses catabolic effects of interleukin-1beta through alpha5beta1 and alphaVbeta3 integrins in nucleus pulposus cells: implications in intervertebral disc degeneration, J. Biol. Chem. 289 (2014) 7374-7387.

[33] R. Samarakoon, A.D. Dobberfuhl, C. Cooley, J.M. Overstreet, S. Patel, R. Goldschmeding, et al., Induction of renal fibrotic genes by TGF-beta1 requires EGFR activation, p53 and reactive oxygen species, Cell. Signal. 25 (2013) 2198-2209.

[34] R. Urtasun, M.U. Latasa, M.I. Demartis, S. Balzani, S. Goni, O. Garcia-Irigoyen, et al., Connective tissue growth factor autocriny in human hepatocellular carcinoma: oncogenic role and regulation by epidermal growth factor receptor/yesassociated protein-mediated activation, Hepatology 54 (2011) 2149-2158. 
[35] J.H. Li, H.J. Zhu, X.R. Huang, K.N. Lai, R.J. Johnson, H.Y. Lan, Smad7 inhibits fibrotic effect of TGF-beta on renal tubular epithelial cells by blocking Smad2 activation, J. Am. Soc. Nephrol. 13 (2002) 1464-1472.

[36] H.R. Bao, X.J. Liu, Y.L. Li, X. Men, X.L. Zeng, Sinomenine attenuates airway inflammation and remodeling in a mouse model of asthma, Mol. Med. Rep. 13 (2016) 2415-2422.

[37] W.H. Yang, M.Y. Kuo, C.M. Liu, Y.T. Deng, H.H. Chang, J. Z. Chang, Curcumin inhibits TGFbeta1-induced CCN2 via Src, JNK, and Smad3 in gingiva, J. Dent. Res. 92 (2013) 629-634.

[38] M. Fehrholz, K. Glaser, C.P. Speer, S. Seidenspinner, B. Ottensmeier, S. Kunzmann, Caffeine modulates glucocorticoid-induced expression of CTGF in lung epithelial cells and fibroblasts, Respir. Res. 18 (2017) 1-11.

[39] J.H. Mun, Y.M. Kim, B.S. Kim, J.H. Kim, M.B. Kim, H.C. Ko, Simvastatin inhibits transforming growth factor-beta1induced expression of type I collagen, CTGF, and alphaSMA in keloid fibroblasts, Wound Repair Regen. 22 (2014) 125-133.

[40] S. Kondo, N. Tanaka, S. Kubota, Y. Mukudai, G. Yosimichi, T. Sugahara, et al., Novel angiogenic inhibitor DN-9693 that inhibits post-transcriptional induction of connective tissue growth factor (CTGF/CCN2) by vascular endothelial growth factor in human endothelial cells, Mol. Cancer Ther. 5 (2006) 129-137.

[41] S. Rawal, P.E. Munasinghe, P.T. Nagesh, J.K.S. Lew, G.T. Jones, M.J.A. Williams, et al., Down-regulation of miR-15a/b accelerates fibrotic remodelling in the type 2 diabetic human and mouse heart, Clin. Sci. (Lond.) 131 (2017) 847-863.

[42] T. Ohgawara, S. Kubota, H. Kawaki, S. Kondo, T. Eguchi, N. Kurio, et al., Regulation of chondrocytic phenotype by micro RNA 18a: involvement of CCN2/CTGF as a major target gene, FEBS Lett. 583 (2009) 1006-1010.

[43] K.Y. Kim, Y.J. Hwang, M.K. Jung, J. Choe, Y. Kim, S. Kim, et al., A multifunctional protein EWS regulates the expression of Drosha and microRNAs, Cell Death Differ. 21 (2014) 136-145.

[44] Y.C. Chen, B.C. Chen, C.C. Yu, S.H. Lin, C.H. Lin, MiR-19a, $-19 b$, and $-26 b$ mediate CTGF expression and pulmonary fibroblast differentiation, J. Cell. Physiol. 231 (2016) 2236-2248.

[45] H. Liang, C. Xu, Z. Pan, Y. Zhang, Z. Xu, Y. Chen, et al., The antifibrotic effects and mechanisms of microRNA-26a action in idiopathic pulmonary fibrosis, Mol. Ther. 22 (2014) 1122-1133.

[46] R.F. Duisters, A.J. Tijsen, B. Schroen, J.J. Leenders, V. Lentink, I. van der Made, et al., miR-133 and miR-30 regulate connective tissue growth factor: implications for a role of microRNAs in myocardial matrix remodeling, Circ. Res. 104 (2009) 170-178.

[47] Q. Han, H.Y. Zhang, B.L. Zhong, X.J. Wang, B. Zhang, H. Chen, MicroRNA-145 inhibits cell migration and invasion and regulates epithelial-mesenchymal transition (EMT) by targeting connective tissue growth factor (CTGF) in esophageal squamous cell carcinoma, Med. Sci. Monit. 22 (2016) 3925-3934.

[48] H.K. Lee, A. Bier, S. Cazacu, S. Finniss, C. Xiang, H. Twito, et al., MicroRNA-145 is downregulated in glial tumors and regulates glioma cell migration by targeting connective tissue growth factor, PLoS One 8 (2013) 1-12.

[49] H. Xie, Y. Zhao, S. Caramuta, C. Larsson, W.O. Lui, miR205 expression promotes cell proliferation and migration of human cervical cancer cells, PLoS One 7 (2012) 1-12.
[50] L. Chen, A. Charrier, Y. Zhou, R. Chen, B. Yu, K. Agarwal, et al., Epigenetic regulation of connective tissue growth factor by microRNA-214 delivery in exosomes from mouse or human hepatic stellate cells, Hepatology 59 (2014) 1118-1129.

[51] L. Chen, R. Chen, S. Kemper, A. Charrier, D.R. Brigstock, Suppression of fibrogenic signaling in hepatic stellate cells by Twist1-dependent microRNA-214 expression: role of exosomes in horizontal transfer of Twist1, Am. J. Physiol. Gastrointest. Liver Physiol. 309 (2015) 491-499.

[52] K.J. Alam, J.S. Mo, S.H. Han, W.C. Park, H.S. Kim, K.J. Yun, et al., MicroRNA 375 regulates proliferation and migration of colon cancer cells by suppressing the CTGF-EGFR signaling pathway, Int. J. Cancer 141 (2017) 1614-1629.

[53] K.G. Gerritsen, N. Bovenschen, T.Q. Nguyen, D. Sprengers, M.P. Koeners, A.N. van Koppen, et al., Rapid hepatic clearance of full length CCN-2/CTGF: a putative role for LRP1-mediated endocytosis, J. Cell Commun. Signal. 10 (2016) 295-303.

[54] K.G. Gerritsen, A.C. Abrahams, H.P. Peters, T.Q. Nguyen, M.P. Koeners, C.H. den Hoedt, et al., Effect of GFR on plasma N-terminal connective tissue growth factor (CTGF) concentrations, Am. J. Kidney Dis. 59 (2012) 619-627.

[55] K.G. Gerritsen, H.P. Peters, T.Q. Nguyen, M.P. Koeners, J. F. Wetzels, J.A. Joles, et al., Renal proximal tubular dysfunction is a major determinant of urinary connective tissue growth factor excretion, Am. J. Physiol. Ren. Physiol. 298 (2010) 1457-1464.

[56] L.F. Lau, Cell surface receptors for CCN proteins, J. Cell Commun. Signal. 10 (2016) 121-127.

[57] R. Gao, D.R. Brigstock, Connective tissue growth factor (CCN2) induces adhesion of rat activated hepatic stellate cells by binding of its $\mathrm{C}$-terminal domain to integrin alpha(v) beta(3) and heparan sulfate proteoglycan, J. Biol. Chem. 279 (2004) 8848-8855.

[58] R. Gao, D.R. Brigstock, Connective tissue growth factor (CCN2) in rat pancreatic stellate cell function: integrin alpha5beta1 as a novel CCN2 receptor, Gastroenterology 129 (2005) 1019-1030.

[59] M. Hoshijima, T. Hattori, M. Inoue, D. Araki, H. Hanagata, A. Miyauchi, et al., CT domain of CCN2/CTGF directly interacts with fibronectin and enhances cell adhesion of chondrocytes through integrin alpha5beta1, FEBS Lett. 580 (2006) 1376-1382.

[60] X. Wang, S.V. McLennan, T.J. Allen, S.M. Twigg, Regulation of pro-inflammatory and pro-fibrotic factors by CCN2/ CTGF in H9c2 cardiomyocytes, J. Cell Commun. Signal. 4 (2010) 15-23.

[61] L. Kennedy, S. Liu, X. Shi-Wen, Y. Chen, M. Eastwood, M. Sabetkar, et al., CCN2 is necessary for the function of mouse embryonic fibroblasts, Exp. Cell Res. 313 (2007) 952-964.

[62] E. Aoyama, S. Kubota, M. Takigawa, CCN2/CTGF binds to fibroblast growth factor receptor 2 and modulates its signaling, FEBS Lett. 586 (2012) 4270-4275.

[63] E. Aoyama, S. Kubota, H.M. Khattab, T. Nishida, M. Takigawa, CCN2 enhances RANKL-induced osteoclast differentiation via direct binding to RANK and OPG, Bone 73 (2015) 242-248.

[64] T. Nishida, K. Emura, S. Kubota, K.M. Lyons, M. Takigawa, CCN family 2/connective tissue growth factor (CCN2/ CTGF) promotes osteoclastogenesis via induction of and interaction with dendritic cell-specific transmembrane protein (DC-STAMP), J. Bone Miner. Res. 26 (2011) 351-363.

[65] T.D. Blalock, D.J. Gibson, M.R. Duncan, S.S. Tuli, G.R. Grotendorst, G.S. Schultz, A connective tissue growth 
factor signaling receptor in corneal fibroblasts, Invest. Ophthalmol. Vis. Sci. 53 (2012) 3387-3394.

[66] L. Pi, A.K. Shenoy, J. Liu, S. Kim, N. Nelson, H. Xia, et al., CCN2/CTGF regulates neovessel formation via targeting structurally conserved cystine knot motifs in multiple angiogenic regulators, FASEB J. 26 (2012) 3365-3379.

[67] T. Nishida, S. Kubota, E. Aoyama, D. Janune, A. Maeda, M. Takigawa, Effect of CCN2 on FGF2-induced proliferation and MMP9 and MMP13 productions by chondrocytes, Endocrinology 152 (2011) 4232-4241.

[68] J.G. Abreu, N.I. Ketpura, B. Reversade, E.M. De Robertis, Connective-tissue growth factor (CTGF) modulates cell signalling by BMP and TGF-beta, Nat. Cell Biol. 4 (2002) 599-604.

[69] J.R. Montford, S.B. Furgeson, A new CTGF target in renal fibrosis, Kidney Int. 92 (2017) 784-786.

[70] S. Kubota, M. Takigawa, The CCN family acting throughout the body: recent research developments, Biomol. Concepts 4 (2013) 477-494.

[71] K.E. Lipson, C. Wong, Y. Teng, S. Spong, CTGF is a central mediator of tissue remodeling and fibrosis and its inhibition can reverse the process of fibrosis, Fibrogenesis Tissue Repair 5 (2012) 1-8.

[72] A.G. Lambi, T.L. Pankratz, C. Mundy, M. Gannon, M.F. Barbe, J.T. Richtsmeier, et al., The skeletal site-specific role of connective tissue growth factor in prenatal osteogenesis, Dev. Dyn. 241 (2012) 1944-1959.

[73] J.T. Tarr, T.G. Visser, J.E. Moon, H. Hendesi, M.F. Barbe, J. $\mathrm{P}$. Bradley, et al., The pivotal role of CCN2 in mammalian palatogenesis, J. Cell Commun. Signal. 11 (2017) 25-37.

[74] F. Hall-Glenn, R.A. De Young, B.L. Huang, B. van Handel, J.J. Hofmann, T.T. Chen, et al., CCN2/connective tissue growth factor is essential for pericyte adhesion and endothelial basement membrane formation during angiogenesis, PLoS One 7 (2012) 1-11.

[75] Y. Murase, T. Hattori, E. Aoyama, T. Nishida, A. MaedaUematsu, H. Kawaki, et al., Role of CCN2 in amino acid metabolism of chondrocytes, J. Cell. Biochem. 117 (2016) 927-937.

[76] T. Nishida, S. Kubota, E. Aoyama, D. Janune, K.M. Lyons, M. Takigawa, CCN family protein 2 (CCN2) promotes the early differentiation, but inhibits the terminal differentiation of skeletal myoblasts, J. Biochem. 157 (2015) 91-100.

[77] D.P. Aguiar, G.C. de Farias, E.B. de Sousa, J. de Mattos Coelho-Aguiar, J.C. Lobo, P.L. Casado, et al., New strategy to control cell migration and metastasis regulated by $\mathrm{CCN} 2 /$ CTGF, Cancer Cell Int. 14 (2014) 1-7.

[78] S. Kato, S. Yokoyama, Y. Hayakawa, L. Li, Y. Iwakami, H. Sakurai, et al., P38 pathway as a key downstream signal of connective tissue growth factor to regulate metastatic potential in non-small-cell lung cancer, Cancer Sci. 107 (2016) 1416-1421.

[79] H. Yeger, B. Perbal, CCN family of proteins: critical modulators of the tumor cell microenvironment, J. Cell Commun. Signal. 10 (2016) 229-240.

[80] N. Wahab, D. Cox, A. Witherden, R.M. Mason, Connective tissue growth factor (CTGF) promotes activated mesangial cell survival via up-regulation of mitogen-activated protein kinase phosphatase-1 (MKP-1), Biochem. J. 406 (2007) 131-138

[81] N. Abdel-Wahab, B.S. Weston, T. Roberts, R.M. Mason, Connective tissue growth factor and regulation of the mesangial cell cycle: role in cellular hypertrophy, J. Am. Soc. Nephrol. 13 (2002) 2437-2445.
[82] F.A. Valentijn, L.L. Falke, T.Q. Nguyen, R. Goldschmeding, Cellular senescence in the aging and diseased kidney, J. Cell Commun. Signal. 12 (2017) 69-82.

[83] T.A. Wynn, T.R. Ramalingam, Mechanisms of fibrosis: therapeutic translation for fibrotic disease, Nat. Med. 18 (2012) 1028-1040.

[84] T. Vanhove, R. Goldschmeding, D. Kuypers, Kidney fibrosis: origins and interventions, Transplantation 101 (2017) 713-726.

[85] P. Gal, L. Varinska, L. Faber, S. Novak, P. Szabo, P. Mitrengova, et al., How signaling molecules regulate tumor microenvironment: parallels to wound repair, Molecules 22 (2017) 1-17.

[86] L. Yang, T.Y. Besschetnova, C.R. Brooks, J.V. Shah, J.V. Bonventre, Epithelial cell cycle arrest in G2/M mediates kidney fibrosis after injury, Nat. Med. 16 (2010) 535-543.

[87] J.V. Bonventre, Maladaptive proximal tubule repair: cell cycle arrest, Nephron Clin. Pract. 127 (2014) 61-64.

[88] R. Samarakoon, S. Helo, A.D. Dobberfuhl, N.S. Khakoo, L. Falke, J.M. Overstreet, et al., Loss of tumour suppressor PTEN expression in renal injury initiates SMAD3- and p53dependent fibrotic responses, J. Pathol. 236 (2015) 421-432.

[89] R. Samarakoon, A. Rehfuss, N.S. Khakoo, L.L. Falke, A.D. Dobberfuhl, S. Helo, et al., Loss of expression of protein phosphatase magnesium-dependent $1 \mathrm{~A}$ during kidney injury promotes fibrotic maladaptive repair, FASEB J. 30 (2016) 3308-3320.

[90] Q. Jia, Q. Dong, L. Qin, CCN: core regulatory proteins in the microenvironment that affect the metastasis of hepatocellular carcinoma? Oncotarget 7 (2016) 1203-1214.

[91] C.C. Chang, B.R. Lin, T.S. Wu, Y.M. Jeng, M.L. Kuo, Input of microenvironmental regulation on colorectal cancer: role of the CCN family, World J. Gastroenterol. 20 (2014) 6826-6831.

[92] I. Ubink, E.R. Verhaar, O. Kranenburg, R. Goldschmeding, A potential role for CCN2/CTGF in aggressive colorectal cancer, J. Cell Commun. Signal. 10 (2016) 223-227.

[93] D. Lai, K.C. Ho, Y. Hao, X. Yang, Taxol resistance in breast cancer cells is mediated by the hippo pathway component TAZ and its downstream transcriptional targets Cyr61 and CTGF, Cancer Res. 71 (2011) 2728-2738.

[94] M. Bartucci, R. Dattilo, C. Moriconi, A. Pagliuca, M. Mottolese, G. Federici, et al., TAZ is required for metastatic activity and chemoresistance of breast cancer stem cells, Oncogene 34 (2015) 681-690.

[95] J. Li, L. Ye, S. Owen, H.P. Weeks, Z. Zhang, W.G. Jiang, Emerging role of CCN family proteins in tumorigenesis and cancer metastasis (review), Int. J. Mol. Med. 36 (2015) 1451-1463.

[96] Q. Wu, M. Jorgensen, J. Song, J. Zhou, C. Liu, L. Pi, Members of the Cyr61/CTGF/NOV protein family: emerging players in hepatic progenitor cell activation and intrahepatic cholangiocarcinoma, Gastroenterol. Res. Pract. 2016 (2016) 1-9.

[97] Y.L. Wu, H.Y. Li, X.P. Zhao, J.Y. Jiao, D.X. Tang, L.J. Yan, et al., Mesenchymal stem cell-derived CCN2 promotes the proliferation, migration and invasion of human tongue squamous cell carcinoma cells, Cancer Sci. 108 (2017) 897-909.

[98] J. Hutchenreuther, K.M. Vincent, D.E. Carter, L.M. Postovit, A. Leask, CCN2 expression by tumor stroma is required for melanoma metastasis, J. Invest. Dermatol. 135 (2015) 2805-2813.

[99] E.C. Finger, C.F. Cheng, T.R. Williams, E.B. Rankin, B. Bedogni, L. Tachiki, et al., CTGF is a therapeutic target for metastatic melanoma, Oncogene 33 (2014) 1093-1100. 
[100] E.J. Kuiper, F.A. Van Nieuwenhoven, M.D. de Smet, J.C. van Meurs, M.W. Tanck, N. Oliver, et al., The angio-fibrotic switch of VEGF and CTGF in proliferative diabetic retinopathy, PLoS One 3 (2008) 1-7.

[101] L. Yan, B. Chaqour, Cysteine-rich protein 61 (CCN1) and connective tissue growth factor (CCN2) at the crosshairs of ocular neovascular and fibrovascular disease therapy, J. Cell Commun. Signal. 7 (2013) 253-263.

[102] D.M. Wallace, A.F. Clark, K.E. Lipson, D. Andrews, J.K. Crean, C.J. O'Brien, Anti-connective tissue growth factor antibody treatment reduces extracellular matrix production in trabecular meshwork and lamina cribrosa cells, Invest. Ophthalmol. Vis. Sci. 54 (2013) 7836-7848.

[103] Z. Zhao, L. Ho, J. Wang, W. Qin, E.D. Festa, C. Mobbs, et al., Connective tissue growth factor (CTGF) expression in the brain is a downstream effector of insulin resistanceassociated promotion of Alzheimer's disease beta-amyloid neuropathology, FASEB J. 19 (2005) 2081-2082.

[104] L. Passerini, P. Bernasconi, F. Baggi, P. Confalonieri, F. Cozzi, F. Cornelio, et al., Fibrogenic cytokines and extent of fibrosis in muscle of dogs with X-linked golden retriever muscular dystrophy, Neuromuscul. Disord. 12 (2002) 828-835.

[105] J.D. Porter, A.P. Merriam, P. Leahy, B. Gong, J. Feuerman, G. Cheng, et al., Temporal gene expression profiling of dystrophin-deficient (mdx) mouse diaphragm identifies conserved and muscle group-specific mechanisms in the pathogenesis of muscular dystrophy, Hum. Mol. Genet. 13 (2004) 257-269.

[106] G. Sun, K. Haginoya, Y. Wu, Y. Chiba, T. Nakanishi, A. Onuma, et al., Connective tissue growth factor is overexpressed in muscles of human muscular dystrophy, J. Neurol. Sci. 267 (2008) 48-56.

[107] M.G. Morales, M.J. Acuna, D. Cabrera, R. Goldschmeding, E. Brandan, The pro-fibrotic connective tissue growth factor (CTGF/CCN2) correlates with the number of necroticregenerative foci in dystrophic muscle, J. Cell Commun. Signal. (2017) 1-9.

[108] Y. Song, S. Yao, Y. Liu, L. Long, H. Yang, Q. Li, et al., Expression levels of TGF-beta1 and CTGF are associated with the severity of Duchenne muscular dystrophy, Exp. Ther. Med. 13 (2017) 1209-1214.

[109] N. Hou, Y. Wen, X. Yuan, H. Xu, X. Wang, F. Li, et al., Activation of Yap1/Taz signaling in ischemic heart disease and dilated cardiomyopathy, Exp. Mol. Pathol. 103 (2017) 267-275.

[110] C. Vial, L.M. Zuniga, C. Cabello-Verrugio, P. Canon, R. Fadic, E. Brandan, Skeletal muscle cells express the profibrotic cytokine connective tissue growth factor (CTGF/CCN2), which induces their dedifferentiation, J. Cell. Physiol. 215 (2008) 410-421.

[111] M.G. Morales, J. Gutierrez, C. Cabello-Verrugio, D. Cabrera, K.E. Lipson, R. Goldschmeding, et al., Reducing CTGF/CCN2 slows down mdx muscle dystrophy and improves cell therapy, Hum. Mol. Genet. 22 (2013) 4938-4951.

[112] D. Abraham, Connective tissue growth factor: growth factor, matricellular organizer, fibrotic biomarker or molecular target for anti-fibrotic therapy in SSc? Rheumatology (Oxford) 47 (2008) 8-9.

[113] S. Sato, T. Nagaoka, M. Hasegawa, T. Tamatani, T. Nakanishi, M. Takigawa, et al., Serum levels of connective tissue growth factor are elevated in patients with systemic sclerosis: association with extent of skin sclerosis and severity of pulmonary fibrosis, J. Rheumatol. 27 (2000) 149-154.

[114] S. Chujo, F. Shirasaki, M. Kondo-Miyazaki, Y. Ikawa, K. Takehara, Role of connective tissue growth factor and its interaction with basic fibroblast growth factor and macrophage chemoattractant protein-1 in skin fibrosis, J. Cell. Physiol. 220 (2009) 189-195.

[115] Y. Asano, Future treatments in systemic sclerosis, J. Dermatol. 37 (2010) 54-70.

[116] A. Leask, Towards an anti-fibrotic therapy for scleroderma: targeting myofibroblast differentiation and recruitment, Fibrogenesis Tissue Repair 3 (2010) 1-5.

[117] K. Makino, T. Makino, L. Stawski, K.E. Lipson, A. Leask, M. Trojanowska, Anti-connective tissue growth factor (CTGF/ CCN2) monoclonal antibody attenuates skin fibrosis in mice models of systemic sclerosis, Arthritis Res. Ther. 19 (2017) $1-10$.

[118] S.K. Parapuram, X. Shi-wen, C. Elliott, I.D. Welch, H. Jones, M. Baron, et al., Loss of PTEN expression by dermal fibroblasts causes skin fibrosis, J. Invest. Dermatol. 131 (2011) 1996-2003.

[119] D. Gentile, P.E. Lazzerini, A. Gamberucci, M. Natale, E. Selvi, F. Vanni, et al., Searching novel therapeutic targets for scleroderma: P2X7-receptor is up-regulated and promotes a fibrogenic phenotype in systemic sclerosis fibroblasts, Front. Pharmacol. 8 (2017) 1-13.

[120] T.M. Maher, Idiopathic pulmonary fibrosis: pathobiology of novel approaches to treatment, Clin. Chest Med. 33 (2012) 69-83.

[121] J.A. Lasky, L.A. Ortiz, B. Tonthat, G.W. Hoyle, M. Corti, G. Athas, et al., Connective tissue growth factor mRNA expression is upregulated in bleomycin-induced lung fibrosis, Am. J. Phys. 275 (1998) 365-371.

[122] S. Liu, X. Shi-wen, D.J. Abraham, A. Leask, CCN2 is required for bleomycin-induced skin fibrosis in mice, Arthritis Rheum. 63 (2011) 239-246.

[123] T. Mori, S. Kawara, M. Shinozaki, N. Hayashi, T. Kakinuma, A. Igarashi, et al., Role and interaction of connective tissue growth factor with transforming growth factor-beta in persistent fibrosis: a mouse fibrosis model, J. Cell. Physiol. 181 (1999) 153-159.

[124] P. Bonniaud, G. Martin, P.J. Margetts, K. Ask, J. Robertson, J. Gauldie, et al., Connective tissue growth factor is crucial to inducing a profibrotic environment in "fibrosis-resistant" BALB/c mouse lungs, Am. J. Respir. Cell Mol. Biol. 31 (2004) 510-516.

[125] M. Ponticos, A.M. Holmes, X. Shi-wen, P. Leoni, K. Khan, V. S. Rajkumar, et al., Pivotal role of connective tissue growth factor in lung fibrosis: MAPK-dependent transcriptional activation of type I collagen, Arthritis Rheum. 60 (2009) 2142-2155.

[126] S. Bickelhaupt, C. Erbel, C. Timke, U. Wirkner, M. Dadrich, P. Flechsig, et al., Effects of CTGF blockade on attenuation and reversal of radiation-induced pulmonary fibrosis, $\mathrm{J}$. Natl. Cancer Inst. 109 (2017) 1-11.

[127] L. Plantier, H. Renaud, R. Respaud, S. Marchand-Adam, B. Crestani, Transcriptome of cultured lung fibroblasts in idiopathic pulmonary fibrosis: meta-analysis of publically available microarray datasets reveals repression of inflammation and immunity pathways, Int. J. Mol. Sci. 17 (2016) $1-11$.

[128] J.T. Allen, R.A. Knight, C.A. Bloor, M.A. Spiteri, Enhanced insulin-like growth factor binding protein-related protein 2 (connective tissue growth factor) expression in patients with 
idiopathic pulmonary fibrosis and pulmonary sarcoidosis, Am. J. Respir. Cell Mol. Biol. 21 (1999) 693-700.

[129] M. Kono, Y. Nakamura, T. Suda, M. Kato, Y. Kaida, D. Hashimoto, et al., Plasma CCN2 (connective tissue growth factor; CTGF) is a potential biomarker in idiopathic pulmonary fibrosis (IPF), Clin. Chim. Acta 412 (2011) 2211-2215.

[130] L.H. Pan, K. Yamauchi, M. Uzuki, T. Nakanishi, M. Takigawa, H. Inoue, et al., Type II alveolar epithelial cells and interstitial fibroblasts express connective tissue growth factor in IPF, Eur. Respir. J. 17 (2001) 1220-1227.

[131] G. Raghu, M.B. Scholand, J. de Andrade, L. Lancaster, Y. Mageto, J. Goldin, et al., FG-3019 anti-connective tissue growth factor monoclonal antibody: results of an open-label clinical trial in idiopathic pulmonary fibrosis, Eur. Respir. J. 47 (2016) 1481-1491.

[132] P.W. Noble, C. Albera, W.Z. Bradford, U. Costabel, M.K. Glassberg, D. Kardatzke, et al., Pirfenidone in patients with idiopathic pulmonary fibrosis (CAPACITY): two randomised trials, Lancet 377 (2011) 1760-1769.

[133] S.D. Nathan, Evaluating new treatment options, Am. J. Manag. Care 23 (2017) 183-190.

[134] R.M. Prieto Castro, M.E. Leva Vallejo, J.C. Regueiro Lopez, F.J. Anglada Curado, J. Alvarez Kindelan, M.J. Requena Tapia, Combined treatment with vitamin $\mathrm{E}$ and colchicine in the early stages of Peyronie's disease, BJU Int. 91 (2003) 522-524.

[135] A. Leask, Getting to the heart of the matter: new insights into cardiac fibrosis, Circ. Res. 116 (2015) 1269-1276.

[136] M.M. Chen, A. Lam, J.A. Abraham, G.F. Schreiner, A.H. Joly, CTGF expression is induced by TGF- beta in cardiac fibroblasts and cardiac myocytes: a potential role in heart fibrosis, J. Mol. Cell. Cardiol. 32 (2000) 1805-1819.

[137] S.M. Chuva de Sousa Lopes, A. Feijen, J. Korving, O. Korchynskyi, J. Larsson, S. Karlsson, et al., Connective tissue growth factor expression and Smad signaling during mouse heart development and myocardial infarction, Dev. Dyn. 231 (2004) 542-550.

[138] X. Wang, S.V. McLennan, T.J. Allen, T. Tsoutsman, C. Semsarian, S.M. Twigg, Adverse effects of high glucose and free fatty acid on cardiomyocytes are mediated by connective tissue growth factor, Am. J. Physiol. Cell Physiol. 297 (2009) 1490-1500.

[139] J. Tank, D. Lindner, X. Wang, A. Stroux, L. Gilke, M. Gast, et al., Single-target RNA interference for the blockade of multiple interacting proinflammatory and profibrotic pathways in cardiac fibroblasts, J. Mol. Cell. Cardiol. 66 (2014) 141-156.

[140] M.S. Fontes, E.L. Kessler, L. van Stuijvenberg, M.A. Brans, L.L. Falke, B. Kok, et al., CTGF knockout does not affect cardiac hypertrophy and fibrosis formation upon chronic pressure overload, J. Mol. Cell. Cardiol. 88 (2015) 82-90.

[141] F. Accornero, J.H. van Berlo, R.N. Correll, J.W. Elrod, M.A. Sargent, A. York, et al., Genetic analysis of connective tissue growth factor as an effector of transforming growth factor beta signaling and cardiac remodeling, Mol. Cell. Biol. 35 (2015) 2154-2164.

[142] J. Gravning, S. Orn, O.J. Kaasboll, V.N. Martinov, C. Manhenke, K. Dickstein, et al., Myocardial connective tissue growth factor (CCN2/CTGF) attenuates left ventricular remodeling after myocardial infarction, PLoS One 7 (2012) 1-15.

[143] C.M. Tang, M. Zhang, L. Huang, Z.Q. Hu, J.N. Zhu, Z. Xiao, et al., CircRNA_000203 enhances the expression of fibrosis-associated genes by derepressing targets of miR- 26b-5p, Col1a2 and CTGF, in cardiac fibroblasts, Sci. Rep. 7 (2017) 1-9.

[144] Z.W. Huang, L.H. Tian, B. Yang, R.M. Guo, Long noncoding RNA H19 acts as a competing endogenous RNA to mediate CTGF expression by sponging miR-455 in cardiac fibrosis, DNA Cell Biol. 36 (2017) 759-766.

[145] G. Qiao, D. Xia, Z. Cheng, G. Zhang, miR132 in atrial fibrillation directly targets connective tissue growth factor, Mol. Med. Rep. 16 (2017) 4143-4150.

[146] M. Chatzifrangkeskou, C. Le Dour, W. Wu, J.P. Morrow, L. C. Joseph, M. Beuvin, et al., ERK1/2 directly acts on CTGF/ CCN2 expression to mediate myocardial fibrosis in cardiomyopathy caused by mutations in the lamin A/C gene, Hum. Mol. Genet. 25 (2016) 2220-2233.

[147] Y.E. Koshman, M.D. Sternlicht, T. Kim, C.P. O'Hara, C.A. Koczor, W. Lewis, et al., Connective tissue growth factor regulates cardiac function and tissue remodeling in a mouse model of dilated cardiomyopathy, J. Mol. Cell. Cardiol. 89 (2015) 214-222.

[148] J.F. Perz, G.L. Armstrong, L.A. Farrington, Y.J. Hutin, B.P. Bell, The contributions of hepatitis B virus and hepatitis C virus infections to cirrhosis and primary liver cancer worldwide, J. Hepatol. 45 (2006) 529-538.

[149] O.A. Gressner, C. Gao, Monitoring fibrogenic progression in the liver, Clin. Chim. Acta 433 (2014) 111-122.

[150] S.L. Friedman, Mechanisms of hepatic fibrogenesis, Gastroenterology 134 (2008) 1655-1669.

[151] O.A. Gressner, A.M. Gressner, Connective tissue growth factor: a fibrogenic master switch in fibrotic liver diseases, Liver Int. 28 (2008) 1065-1079.

[152] J. George, S.S. Wang, A.M. Sevcsik, M. Sanicola, R.L. Cate, V.E. Koteliansky, et al., Transforming growth factorbeta initiates wound repair in rat liver through induction of the EllIA-fibronectin splice isoform, Am. J. Pathol. 156 (2000) 115-124.

[153] W.R. Jarnagin, D.C. Rockey, V.E. Koteliansky, S.S. Wang, D.M. Bissell, Expression of variant fibronectins in wound healing: cellular source and biological activity of the EIIIA segment in rat hepatic fibrogenesis, J. Cell Biol. 127 (1994) 2037-2048.

[154] K. Yoshida, H. Munakata, Connective tissue growth factor binds to fibronectin through the type I repeat modules and enhances the affinity of fibronectin to fibrin, Biochim. Biophys. Acta 1770 (2007) 672-680.

[155] A.W. Rachfal, D.R. Brigstock, Connective tissue growth factor (CTGF/CCN2) in hepatic fibrosis, Hepatol. Res. 26 (2003) 1-9.

[156] M. Abou-Shady, H. Friess, A. Zimmermann, F.F. di Mola, X. Z. Guo, H.U. Baer, et al., Connective tissue growth factor in human liver cirrhosis, Liver 20 (2000) 296-304.

[157] V. Paradis, D. Dargere, M. Vidaud, A.C. De Gouville, S. Huet, V. Martinez, et al., Expression of connective tissue growth factor in experimental rat and human liver fibrosis, Hepatology 30 (1999) 968-976.

[158] O.A. Gressner, B. Lahme, I. Demirci, A.M. Gressner, R. Weiskirchen, Differential effects of TGF-beta on connective tissue growth factor (CTGF/CCN2) expression in hepatic stellate cells and hepatocytes, J. Hepatol. 47 (2007) 699-710.

[159] Y. Liu, H. Liu, C. Meyer, J. Li, S. Nadalin, A. Konigsrainer, et al., Transforming growth factor-beta (TGF-beta)-mediated connective tissue growth factor (CTGF) expression in hepatic stellate cells requires Stat3 signaling activation, J. Biol. Chem. 288 (2013) 30708-30719. 
[160] Z.Y. Ding, G.N. Jin, H.F. Liang, W. Wang, W.X. Chen, P.K. Datta, et al., Transforming growth factor beta induces expression of connective tissue growth factor in hepatic progenitor cells through Smad independent signaling, Cell. Signal. 25 (2013) 1981-1992.

[161] T. Kodama, T. Takehara, H. Hikita, S. Shimizu, M. Shigekawa, $\mathrm{H}$. Tsunematsu, et al., Increases in p53 expression induce CTGF synthesis by mouse and human hepatocytes and result in liver fibrosis in mice, J. Clin. Invest. 121 (2011) 3343-3356.

[162] G. Huang, D.R. Brigstock, Regulation of hepatic stellate cells by connective tissue growth factor, Front. Biosci. (Landmark Ed.) 17 (2012) 2495-2507.

[163] D. Tampe, M. Zeisberg, Potential approaches to reverse or repair renal fibrosis, Nat. Rev. Nephrol. 10 (2014) 226-237.

[164] R. Kalluri, E.G. Neilson, Epithelial-mesenchymal transition and its implications for fibrosis, J. Clin. Invest. 112 (2003) 1776-1784.

[165] S.L. Friedman, D. Sheppard, J.S. Duffield, S. Violette, Therapy for fibrotic diseases: nearing the starting line, Sci. Transl. Med. 5 (2013) 1-17.

[166] L.L. Falke, S. Gholizadeh, R. Goldschmeding, R.J. Kok, T. Q. Nguyen, Diverse origins of the myofibroblast-implications for kidney fibrosis, Nat. Rev. Nephrol. 11 (2015) 233-244.

[167] G. Huang, D.R. Brigstock, Integrin expression and function in the response of primary culture hepatic stellate cells to connective tissue growth factor (CCN2), J. Cell. Mol. Med. 15 (2011) 1087-1095.

[168] K. Sakai, S. Jawaid, T. Sasaki, G. Bou-Gharios, T. Sakai, Transforming growth factor-beta-independent role of connective tissue growth factor in the development of liver fibrosis, Am. J. Pathol. 184 (2014) 2611-2617.

[169] C. Shi, G. Li, Y. Tong, Y. Deng, J. Fan, Role of CTGF gene promoter methylation in the development of hepatic fibrosis, Am. J. Transl. Res. 8 (2016) 125-132.

[170] K. Sun, Q. Wang, X.H. Huang, PPAR gamma inhibits growth of rat hepatic stellate cells and TGF beta-induced connective tissue growth factor expression, Acta Pharmacol. Sin. 27 (2006) 715-723.

[171] S. Zheng, A. Chen, Curcumin suppresses the expression of extracellular matrix genes in activated hepatic stellate cells by inhibiting gene expression of connective tissue growth factor, Am. J. Physiol. Gastrointest. Liver Physiol. 290 (2006) 883-893.

[172] A. Chen, S. Zheng, Curcumin inhibits connective tissue growth factor gene expression in activated hepatic stellate cells in vitro by blocking NF-kappaB and ERK signalling, Br. J. Pharmacol. 153 (2008) 557-567.

[173] R. Gao, D.R. Brigstock, Low density lipoprotein receptorrelated protein (LRP) is a heparin-dependent adhesion receptor for connective tissue growth factor (CTGF) in rat activated hepatic stellate cells, Hepatol. Res. 27 (2003) 214-220.

[174] J. George, M. Tsutsumi, siRNA-mediated knockdown of connective tissue growth factor prevents $\mathrm{N}$ nitrosodimethylamine-induced hepatic fibrosis in rats, Gene Ther. 14 (2007) 790-803.

[175] G. Li, D. Li, Q. Xie, Y. Shi, S. Jiang, Y. Jin, RNA interfering connective tissue growth factor prevents rat hepatic stellate cell activation and extracellular matrix production, J. Gene Med. 10 (2008) 1039-1047.

[176] C. Hao, Y. Xie, M. Peng, L. Ma, Y. Zhou, Y. Zhang, et al., Inhibition of connective tissue growth factor suppresses hepatic stellate cell activation in vitro and prevents liver fibrosis in vivo, Clin. Exp. Med. 14 (2014) 141-150.
[177] M. Schippers, L. Beljaars, E. Post, S. Lotersztajn, C. RekerSmit, B. Han, et al., Upregulation of Epac-1 in hepatic stellate cells by prostaglandin E2 in liver fibrosis is associated with reduced fibrogenesis, J. Pharmacol. Exp. Ther. 363 (2017) 126-135.

[178] J. Du, Y.Y. Ma, C.H. Yu, Y.M. Li, Effects of pentoxifylline on nonalcoholic fatty liver disease: a meta-analysis, World $\mathrm{J}$. Gastroenterol. 20 (2014) 569-577.

[179] Z. Han, T. Zhu, X. Liu, C. Li, S. Yue, X. Liu, et al., 15-Deoxydelta12, 14-prostaglandin $\mathrm{J} 2$ reduces recruitment of bone marrow-derived monocyte/macrophages in chronic liver injury in mice, Hepatology 56 (2012) 350-360.

[180] S. Bauer, K. Eisinger, R. Wiest, T. Karrasch, M.N. Scherer, S. Farkas, et al., Connective tissue growth factor level is increased in patients with liver cirrhosis but is not associated with complications or extent of liver injury, Regul. Pept. 179 (2012) 10-14.

[181] Y. Liu, New insights into epithelial-mesenchymal transition in kidney fibrosis, J. Am. Soc. Nephrol. 21 (2010) 212-222.

[182] D. Zhou, Y. Liu, Renal fibrosis in 2015: understanding the mechanisms of kidney fibrosis, Nat. Rev. Nephrol. 12 (2016) 68-70.

[183] X.M. Chen, W. Qi, C.A. Pollock, CTGF and chronic kidney fibrosis, Front. Biosci. (Schol. Ed.) (1) (2009) 132-141.

[184] L.L. Falke, R. Goldschmeding, T.Q. Nguyen, A perspective on anti-CCN2 therapy for chronic kidney disease, Nephrol. Dial. Transplant. 29 (2014) 30-37.

[185] B.G. Johnson, S. Ren, G. Karaca, I.G. Gomez, C. Fligny, B. Smith, et al., Connective tissue growth factor domain 4 amplifies fibrotic kidney disease through activation of LDL receptor-related protein 6, J. Am. Soc. Nephrol. 28 (2017) 1769-1782.

[186] N. Sakai, J. Chun, J.S. Duffield, D. Lagares, T. Wada, A.D. Luster, et al., Lysophosphatidic acid signaling through its receptor initiates profibrotic epithelial cell fibroblast communication mediated by epithelial cell derived connective tissue growth factor, Kidney Int. 91 (2017) 628-641.

[187] Y. Ren, C. Du, Y. Shi, J. Wei, H. Wu, H. Cui, The Sirt1 activator, SRT1720, attenuates renal fibrosis by inhibiting CTGF and oxidative stress, Int. J. Mol. Med. 39 (2017) 1317-1324.

[188] H. Kinashi, L.L. Falke, T.Q. Nguyen, N. Bovenschen, J. Aten, A. Leask, et al., Connective tissue growth factor regulates fibrosis-associated renal lymphangiogenesis, Kidney Int. 92 (2017) 850-863.

[189] N. Toda, K. Mori, M. Kasahara, A. Ishii, K. Koga, S. Ohno, et al., Crucial role of mesangial cell-derived connective tissue growth factor in a mouse model of anti-glomerular basement membrane glomerulonephritis, Sci. Rep. 7 (2017) 1-16.

[190] S.P. Gray, M.E. Cooper, Diabetic nephropathy in 2010: alleviating the burden of diabetic nephropathy, Nat. Rev. Nephrol. 7 (2011) 71-73.

[191] M. Murphy, C. Godson, S. Cannon, S. Kato, H.S. Mackenzie, F. Martin, et al., Suppression subtractive hybridization identifies high glucose levels as a stimulus for expression of connective tissue growth factor and other genes in human mesangial cells, J. Biol. Chem. 274 (1999) 5830-5834.

[192] Y. Ito, J. Aten, T.Q. Nguyen, J.A. Joles, S. Matsuo, J.J. Weening, et al., Involvement of connective tissue growth factor in human and experimental hypertensive nephrosclerosis, Nephron Exp. Nephrol. 117 (2011) 9-20.

[193] B.L. Riser, M. Denichilo, P. Cortes, C. Baker, J.M. Grondin, J. Yee, et al., Regulation of connective tissue growth factor 
activity in cultured rat mesangial cells and its expression in experimental diabetic glomerulosclerosis, J. Am. Soc. Nephrol. 11 (2000) 25-38.

[194] P. Roestenberg, F.A. van Nieuwenhoven, J.A. Joles, C. Trischberger, P.P. Martens, N. Oliver, et al., Temporal expression profile and distribution pattern indicate a role of connective tissue growth factor (CTGF/CCN-2) in diabetic nephropathy in mice, Am. J. Physiol. Renal Physiol. 290 (2006) 1344-1354.

[195] S. Wang, M. Denichilo, C. Brubaker, R. Hirschberg, Connective tissue growth factor in tubulointerstitial injury of diabetic nephropathy, Kidney Int. 60 (2001) 96-105.

[196] H. Yokoi, M. Mukoyama, K. Mori, M. Kasahara, T. Suganami, K. Sawai, et al., Overexpression of connective tissue growth factor in podocytes worsens diabetic nephropathy in mice, Kidney Int. 73 (2008) 446-455.

[197] T. Kobayashi, H. Okada, T. Inoue, Y. Kanno, H. Suzuki, Tubular expression of connective tissue growth factor correlates with interstitial fibrosis in type 2 diabetic nephropathy, Nephrol. Dial. Transplant. 21 (2006) 548-549.

[198] T. Turk, J.W. Leeuwis, J. Gray, S.V. Torti, K.M. Lyons, T.Q. Nguyen, et al., BMP signaling and podocyte markers are decreased in human diabetic nephropathy in association with CTGF overexpression, J. Histochem. Cytochem. 57 (2009) 623-631.

[199] K.J. Way, K. Isshiki, K. Suzuma, T. Yokota, D. Zvagelsky, F. J. Schoen, et al., Expression of connective tissue growth factor is increased in injured myocardium associated with protein kinase $\mathrm{C}$ beta2 activation and diabetes, Diabetes 51 (2002) 2709-2718.

[200] E.J. Kuiper, A.N. Witmer, I. Klaassen, N. Oliver, R. Goldschmeding, R.O. Schlingemann, Differential expression of connective tissue growth factor in microglia and pericytes in the human diabetic retina, Br. J. Ophthalmol. 88 (2004) 1082-1087.

[201] A. San Martin, P. Du, A. Dikalova, B. Lassegue, M. Aleman, M.C. Gongora, et al., Reactive oxygen species-selective regulation of aortic inflammatory gene expression in type 2 diabetes, Am. J. Physiol. Heart Circ. Physiol. 292 (2007) 2073-2082.

[202] D.R. Hinton, C. Spee, S. He, S. Weitz, W. Usinger, L. LaBree, et al., Accumulation of $\mathrm{NH} 2$-terminal fragment of connective tissue growth factor in the vitreous of patients with proliferative diabetic retinopathy, Diabetes Care 27 (2004) 758-764.

[203] T.Q. Nguyen, L. Tarnow, S. Andersen, P. Hovind, H.H. Parving, R. Goldschmeding, et al., Urinary connective tissue growth factor excretion correlates with clinical markers of renal disease in a large population of type 1 diabetic patients with diabetic nephropathy, Diabetes Care 29 (2006) 83-88.

[204] T.Q. Nguyen, L. Tarnow, A. Jorsal, N. Oliver, P. Roestenberg, Y. Ito, et al., Plasma connective tissue growth factor is an independent predictor of end-stage renal disease and mortality in type 1 diabetic nephropathy, Diabetes Care 31 (2008) 1177-1182.

[205] M. Guha, Z.G. Xu, D. Tung, L. Lanting, R. Natarajan, Specific down-regulation of connective tissue growth factor attenuates progression of nephropathy in mouse models of type 1 and type 2 diabetes, FASEB J. 21 (2007) 3355-3368.

[206] T.Q. Nguyen, R. Goldschmeding, Bone morphogenetic protein-7 and connective tissue growth factor: novel targets for treatment of renal fibrosis? Pharm. Res. 25 (2008) 2416-2426.
[207] H.Y. Dai, L.N. Ma, Y. Cao, X.L. Chen, H. Shi, Y.P. Fan, et al., Protection of CTGF antibody against diabetic nephropathy in mice via reducing glomerular beta-catenin expression and podocyte epithelial-mesenchymal transition, J. Cell. Biochem. 118 (2017) 3706-3712.

[208] A. Dendooven, K.G. Gerritsen, T.Q. Nguyen, R.J. Kok, R. Goldschmeding, Connective tissue growth factor (CTGF/ CCN2) ELISA: a novel tool for monitoring fibrosis, Biomarkers 16 (2011) 289-301.

[209] S.K. Patel, B. Wai, R.J. Macisaac, S. Grant, E. Velkoska, M. Ord, et al., The CTGF gene $-945 \mathrm{G} / \mathrm{C}$ polymorphism is not associated with cardiac or kidney complications in subjects with type 2 diabetes, Cardiovasc. Diabetol. 11 (2012) 1-7.

[210] B. Wang, R.E. Carter, M.A. Jaffa, S. Nakerakanti, D. Lackland, M. Lopes-Virella, et al., Genetic variant in the promoter of connective tissue growth factor gene confers susceptibility to nephropathy in type 1 diabetes, J. Med. Genet. 47 (2010) 391-397.

[211] S.G. Adler, S. Schwartz, M.E. Williams, C. Arauz-Pacheco, W.K. Bolton, T. Lee, et al., Phase 1 study of anti-CTGF monoclonal antibody in patients with diabetes and microalbuminuria, Clin. J. Am. Soc. Nephrol. 5 (2010) 1420-1428.

[212] R.B. Mannon, Therapeutic targets in the treatment of allograft fibrosis, Am. J. Transplant. 6 (2006) 867-875.

[213] K. Csencsits, S.C. Wood, G. Lu, S.M. Faust, D. Brigstock, E. J. Eichwald, et al., Transforming growth factor beta-induced connective tissue growth factor and chronic allograft rejection, Am. J. Transplant. 6 (2006) 959-966.

[214] H. Okada, T. Kikuta, T. Kobayashi, T. Inoue, Y. Kanno, M. Takigawa, et al., Connective tissue growth factor expressed in tubular epithelium plays a pivotal role in renal fibrogenesis, J. Am. Soc. Nephrol. 16 (2005) 133-143.

[215] O. Cheng, R. Thuillier, E. Sampson, G. Schultz, P. Ruiz, X. Zhang, et al., Connective tissue growth factor is a biomarker and mediator of kidney allograft fibrosis, Am. J. Transplant. 6 (2006) 2292-2306.

[216] C. Metalidis, S.H. van Vuuren, R. Broekhuizen, E. Lerut, M. Naesens, S.J. Bakker, et al., Urinary connective tissue growth factor is associated with human renal allograft fibrogenesis, Transplantation 96 (2013) 494-500.

[217] T. Vanhove, H. Kinashi, T.Q. Nguyen, C. Metalidis, K. Poesen, M. Naesens, et al., Tubulointerstitial expression and urinary excretion of connective tissue growth factor 3 months after renal transplantation predict interstitial fibrosis and tubular atrophy at 5 years in a retrospective cohort analysis, Transpl. Int. 30 (2017) 695-705.

[218] H. Lu, K. Kojima, V.L. Battula, B. Korchin, Y. Shi, Y. Chen, et al., Targeting connective tissue growth factor (CTGF) in acute lymphoblastic leukemia preclinical models: antiCTGF monoclonal antibody attenuates leukemia growth, Ann. Hematol. 93 (2014) 485-492.

[219] N. Dornhofer, S. Spong, K. Bennewith, A. Salim, S. Klaus, N. Kambham, et al., Connective tissue growth factorspecific monoclonal antibody therapy inhibits pancreatic tumor growth and metastasis, Cancer Res. 66 (2006) 5816-5827.

[220] K. Moran-Jones, B.S. Gloss, R. Murali, D.K. Chang, E.K. Colvin, M.D. Jones, et al., Connective tissue growth factor as a novel therapeutic target in high grade serous ovarian cancer, Oncotarget 6 (2015) 44551-44562.

[221] A. Neesse, K.K. Frese, T.E. Bapiro, T. Nakagawa, M.D. Sternlicht, T.W. Seeley, et al., CTGF antagonism with mAb FG-3019 enhances chemotherapy response without 
increasing drug delivery in murine ductal pancreas cancer, Proc. Natl. Acad. Sci. U. S. A. 110 (2013) 12325-12330.

[222] Q. Yin, H.Y. Nan, W.H. Zhang, L.F. Yan, G.B. Cui, X.F. Huang, et al., Pulmonary microvascular endothelial cells from bleomycin-induced rats promote the transformation and collagen synthesis of fibroblasts, J. Cell. Physiol. 226 (2011) 2091-2102.

[223] X. Wang, G. Wu, L. Gou, Z. Liu, X. Wang, X. Fan, et al., A novel single-chain-Fv antibody against connective tissue growth factor attenuates bleomycin-induced pulmonary fibrosis in mice, Respirology 16 (2011) 500-507.

[224] Q. Wang, W. Usinger, B. Nichols, J. Gray, L. Xu, T.W. Seeley, et al., Cooperative interaction of CTGF and TGFbeta in animal models of fibrotic disease, Fibrogenesis Tissue Repair 4 (2011) 1-11.

[225] C.M. Weng, C.C. Yu, M.L. Kuo, B.C. Chen, C.H. Lin, Endothelin-1 induces connective tissue growth factor expression in human lung fibroblasts by ETAR-dependent JNK/AP-1 pathway, Biochem. Pharmacol. 88 (2014) 402-411.

[226] K. Uchio, M. Graham, N.M. Dean, J. Rosenbaum, A. Desmouliere, Down-regulation of connective tissue growth factor and type I collagen mRNA expression by connective tissue growth factor antisense oligonucleotide during experimental liver fibrosis, Wound Repair Regen. 12 (2004) 60-66.

[227] T. Nagaraja, L. Chen, A. Balasubramanian, J.E. Groopman, K. Ghoshal, S.T. Jacob, et al., Activation of the connective tissue growth factor (CTGF)-transforming growth factor beta 1 (TGF-beta 1) axis in hepatitis $C$ virus-expressing hepatocytes, PLoS One 7 (2012) 1-13.

[228] S. Lam, R.N. van der Geest, N.A. Verhagen, F.A. van Nieuwenhoven, I.E. Blom, J. Aten, et al., Connective tissue growth factor and IGF-I are produced by human renal fibroblasts and cooperate in the induction of collagen production by high glucose, Diabetes 52 (2003) 2975-2983.

[229] H. Yokoi, M. Mukoyama, T. Nagae, K. Mori, T. Suganami, K. Sawai, et al., Reduction in connective tissue growth factor by antisense treatment ameliorates renal tubulointerstitial fibrosis, J. Am. Soc. Nephrol. 15 (2004) 1430-1440.

[230] H. Yokoi, M. Mukoyama, A. Sugawara, K. Mori, T. Nagae, $\mathrm{H}$. Makino, et al., Role of connective tissue growth factor in fibronectin expression and tubulointerstitial fibrosis, Am. J. Physiol. Ren. Physiol. 282 (2002) 933-942.

[231] C. Zhang, X. Meng, Z. Zhu, J. Liu, A. Deng, Connective tissue growth factor regulates the key events in tubular epithelial to myofibroblast transition in vitro, Cell Biol. Int. 28 (2004) 863-873.

[232] C. Zhang, Z. Zhu, J. Liu, X. Yang, L. Fu, A. Deng, Role of connective tissue growth factor in extracellular matrix degradation in renal tubular epithelial cells, J. Huazhong Univ. Sci. Technolog. Med. Sci. 27 (2007) 44-47.

[233] I.E. Blom, A.J. van Dijk, L. Wieten, K. Duran, Y. Ito, L. Kleij, et al., In vitro evidence for differential involvement of CTGF, TGFbeta, and PDGF-B in mesangial response to injury, Nephrol. Dial. Transplant. 16 (2001) 1139-1148.

[234] K. Kanemoto, J. Usui, S. Tomari, H. Yokoi, M. Mukoyama, J. Aten, et al., Connective tissue growth factor participates in scar formation of crescentic glomerulonephritis, Lab. Investig. 83 (2003) 1615-1625.

[235] N.A. Wahab, N. Yevdokimova, B.S. Weston, T. Roberts, X. J. Li, H. Brinkman, et al., Role of connective tissue growth factor in the pathogenesis of diabetic nephropathy, Biochem. J. 359 (2001) 77-87.

[236] G. Zhou, C. Li, L. Cai, Advanced glycation end-products induce connective tissue growth factor-mediated renal fibrosis predominantly through transforming growth factor beta-independent pathway, Am. J. Pathol. 165 (2004) 2033-2043.

[237] C.I. Lee, J.Y. Guh, H.C. Chen, W.C. Hung, Y.L. Yang, L.Y. Chuang, Advanced glycation end-product-induced mitogenesis and collagen production are dependent on angiotensin II and connective tissue growth factor in NRK-49F cells, J. Cell. Biochem. 95 (2005) 281-292.

[238] C.I. Lee, J.Y. Guh, H.C. Chen, K.H. Lin, Y.L. Yang, W.C. Hung, et al., Leptin and connective tissue growth factor in advanced glycation end-product-induced effects in NRK49F cells, J. Cell. Biochem. 93 (2004) 940-950.

[239] X. Wang, S.V. McLennan, S.M. Twigg, CCN-2 is upregulated by and mediates effects of matrix bound advanced glycated end-products in human renal mesangial cells, J. Cell Commun. Signal. 5 (2011) 193-200.

[240] H.Y. Dai, M. Zheng, L.L. Lv, R.N. Tang, K.L. Ma, D. Liu, et al., The roles of connective tissue growth factor and integrin-linked kinase in high glucose-induced phenotypic alterations of podocytes, J. Cell. Biochem. 113 (2012) 293-301.

[241] A.J. Booth, K. Csencsits-Smith, S.C. Wood, G. Lu, K.E. Lipson, D.K. Bishop, Connective tissue growth factor promotes fibrosis downstream of TGFbeta and IL-6 in chronic cardiac allograft rejection, Am. J. Transplant. 10 (2010) 220-230.

[242] J.P. Pradere, J. Gonzalez, J. Klein, P. Valet, S. Gres, D. Salant, et al., Lysophosphatidic acid and renal fibrosis, Biochim. Biophys. Acta 1781 (2008) 582-587.

[243] L. Gan, J.X. Xue, X. Li, D.S. Liu, Y. Ge, P.Y. Ni, et al., Blockade of lysophosphatidic acid receptors LPAR1/3 ameliorates lung fibrosis induced by irradiation, Biochem. Biophys. Res. Commun. 409 (2011) 7-13.

[244] N. Desroy, C. Housseman, X. Bock, A. Joncour, N. Bienvenu, L. Cherel, et al., Discovery of 2-[[2-Ethyl-6-[4-[2-(3-hydroxyazetidin-1-yl)-2-oxoethyl]piperazin-1-yl]-8-methyli midazo[1,2-a]pyridin-3-yl]methylamino]-4-(4-fluorophenyl)thiazole-5-carbonitrile (GLPG1690), a first-in-class autotaxin inhibitor undergoing clinical evaluation for the treatment of idiopathic pulmonary fibrosis, J. Med. Chem. 60 (2017) 3580-3590.

[245] X. Zhang, M. Hu, X. Lyu, C. Li, V.J. Thannickal, Y.Y. Sanders, DNA methylation regulated gene expression in organ fibrosis, Biochim. Biophys. Acta 1863 (2017) 2389-2397.

[246] Y. He, C. Huang, X. Lin, J. Li, MicroRNA-29 family, a crucial therapeutic target for fibrosis diseases, Biochimie 95 (2013) $1355-1359$. 